

\title{
Geochemical and Mineralogical Sampling of the Devonian Shales in the Broadtop Synclinorium, Appalachian Basin, in Virginia, West Virginia, Maryland, and Pennsylvania
}

By Catherine B. Enomoto, James L. Coleman, Jr., Christopher S. Swezey, Patrick W. Niemeyer, and Frank T. Dulong

Open-File Report 2015-1061

U.S. Department of the Interior

U.S. Geological Survey 


\section{U.S. Department of the Interior \\ SALLY JEWELL, Secretary}

\section{U.S. Geological Survey \\ Suzette M. Kimball, Acting Director}

U.S. Geological Survey, Reston, Virginia: 2015

For more information on the USGS—-the Federal source for science about the Earth,

its natural and living resources, natural hazards, and the environment-visit

http://www.usgs.gov or call 1-888-ASK-USGS

For an overview of USGS information products, including maps, imagery, and publications, visit http://www.usgs.gov/pubprod

Any use of trade, firm, or product names is for descriptive purposes only and does not imply endorsement by the U.S. Government.

Although this information product, for the most part, is in the public domain, it also may contain copyrighted materials as noted in the text. Permission to reproduce copyrighted items must be secured from the copyright owner

Suggested citation:

Enomoto, C.B., Coleman, J.L., Jr., Swezey, C.S., Niemeyer, P.W., and Dulong, F.T., 2015, Geochemical and mineralogical sampling of the Devonian shales in the Broadtop synclinorium, Appalachian basin, in Virginia, West Virginia, Maryland, and Pennsylvania: U.S. Geological Survey Open-File Report 2015-1061, 32 p., 5 pls., 1 appendix, http://dx.doi.org/10.3133/ofr20151061.

ISSN 2331-1258 (online). 


\section{Contents}

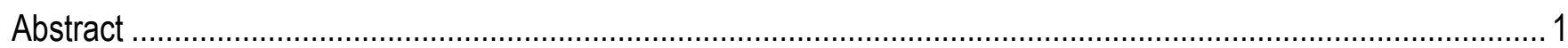

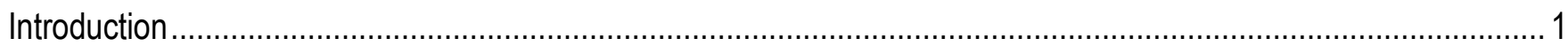

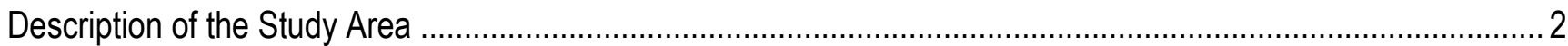



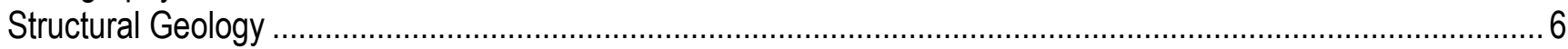

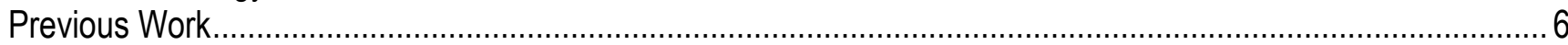

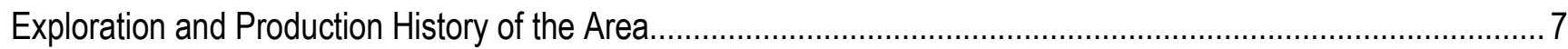

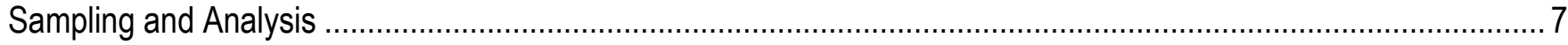

Discussion of Data

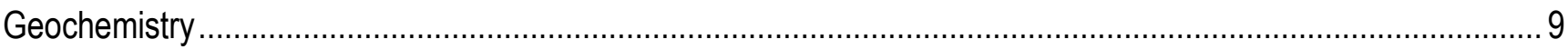

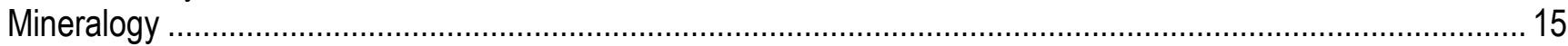

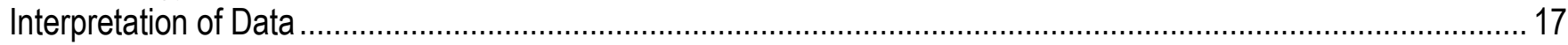

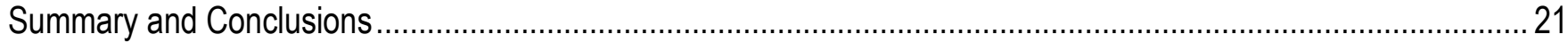



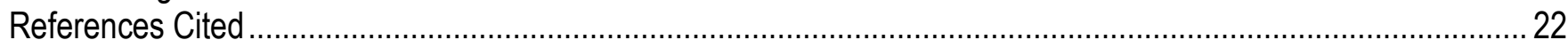

Explanation of Column Headings for Appendix......................................................................................... 30

\section{Plates}

(Available for download in PDF format from http://dx.doi.org/10.3133/ofr20151061.)

1. Map of the study area showing distribution of Middle Devonian shales, locations of cross sections shown on plates 2 and 3 , oil and gas fields, and locations of samples collected for this study.

2. Structural cross section 1 and structure map showing distribution of Middle Devonian shales in the study area.

3. Structural cross section 5 and structure map showing distribution of Middle Devonian shales in the study area.

4. Map of the study area showing distribution of Middle Devonian shales, locations of cross sections shown on plates 2 and 3 , locations of samples collected for this study, and total organic carbon content of each sample.

5. Map of the study area showing distribution of Middle Devonian shales, locations of cross sections shown on plates 2 and 3 , locations of samples collected for this study, and average reflectance of each sample.

\section{Figures}

1. Stratigraphic column of the study area, southeastern West Virginia to south-central Pennsylvania ............... 3

2. Map of major structural features, the study area of this report, and natural gas fields ...............................5

3. Bin-frequency plots of total organic carbon content of Mahantango Formation, Marcellus Shale, and Needmore Shale samples analyzed for this study

4. Bin-frequency plots of the average reflectance values of Mahantango Formation, Marcellus Shale, and Needmore Shale samples analyzed for this study

5. Box-and-whisker plot of no shear and shear versus average reflectance of Marcellus Shale outcrop samples analyzed for this study.

6. Box-and-whisker plot of no shear and shear versus total organic carbon content of Marcellus Shale samples analyzed for this study..... 
7. Box-and-whisker plot of no shear and shear versus bulk-sample chlorite content of Marcellus Shale samples analyzed for this study.

8A. Box-and-whisker plot showing the semiquantitative mineralogy of Mahantango Formation outcrop samples analyzed for this study. 15

$8 B$. Box-and-whisker plot showing the semiquantitative mineralogy of Marcellus Shale outcrop samples analyzed for this study

8C. Box-and-whisker plot showing the semiquantitative mineralogy of Needmore Shale outcrop samples analyzed for this study

9. Histogram of production index (S1/(S1+S2)) for all 105 samples analyzed for this study ......................... 19

10. Ternary plot of quartz, clay, and carbonate mineral content of Marcellus Shale outcrop samples analyzed in this study

\section{Tables}

1. Total organic carbon content of samples analyzed for this study 9

2. Average reflectance values of samples analyzed for this study.....

\section{Appendix}

(Available for download in Excel format from http://dx.doi.org/10.3133/ofr20151061.)

Table of data on samples collected for this study 


\section{Conversion Factors}

Inch/Pound to International System of Units

\begin{tabular}{|c|c|c|}
\hline Multiply & By & To obtain \\
\hline \multicolumn{3}{|c|}{ Length } \\
\hline foot (ft) & 0.3048 & meter (m) \\
\hline mile (mi) & 1.609 & kilometer (km) \\
\hline \multicolumn{3}{|c|}{ Volume } \\
\hline cubic foot $\left(\mathrm{ft}^{3}\right)$ & 0.02832 & cubic meter $\left(\mathrm{m}^{3}\right)$ \\
\hline
\end{tabular}

International System of Units to Inch/Pound

\begin{tabular}{lcl}
\hline \multicolumn{1}{c}{ Multiply } & \multicolumn{1}{c}{ By } & \multicolumn{1}{c}{ To obtain } \\
\hline meter $(\mathrm{m})$ & Length & \\
kilometer $(\mathrm{km})$ & 3.281 & foot $(\mathrm{ft})$ \\
& 0.6214 & mile $(\mathrm{mi})$ \\
\hline cubic meter $\left(\mathrm{m}^{3}\right)$ & Volume & \\
\hline
\end{tabular}

Horizontal coordinate information is referenced to the North American Datum of 1983 (NAD 83). 


\title{
Geochemical and Mineralogical Sampling of the Devonian Shales in the Broadtop Synclinorium, Appalachian Basin, in Virginia, West Virginia, Maryland, and Pennsylvania
}

By Catherine B. Enomoto, James L. Coleman, Jr., Christopher S. Swezey, Patrick W. Niemeyer, and Frank T. Dulong

\begin{abstract}
Reconnaissance field mapping and outcrop sampling for geochemical and mineralogical analyses indicate that the Middle Devonian Marcellus Shale in the Broadtop synclinorium and nearby areas from southeastern West Virginia to south-central Pennsylvania has an organic content sufficiently high and a thermal maturity sufficiently moderate to be considered for a shale gas play. The organic matter-rich Marcellus Shale is present throughout most of the synclinorium, being absent only where it has been eroded from the crest of anticlines. Geochemical analyses of outcrop and well drill-cuttings samples indicate that variable levels of hydrocarbons have been generated and expelled from the kerogen originally in place in the mudstone. The mineralogical characteristics of the Marcellus Shale samples from the study area are conducive to a continuous resource play, but the Middle Devonian strata are folded, faulted, and moderately to heavily sheared in the Broadtop synclinorium.

The presence of conventional anticlinal gas fields in the study area that are productive from the underlying Lower Devonian Oriskany Sandstone suggests that an unconventional (or continuous) shale gas system may be in place within the Marcellus Shale in the study area. Results of this study indicate that the Marcellus Shale in the Broadtop synclinorium generally is similar in organic geochemical nature throughout its extent, and based on the sample analyses, there are no clearly identifiable high potential areas (or "sweet spots") in the study area. This report contains analyses of 132 outcrop and well drill-cuttings samples.
\end{abstract}

\section{Introduction}

The U.S. Geological Survey (USGS) conducted research on Lower and Middle Devonian shales (fig. 1) in the Broadtop synclinorium (Jacobeen and Kanes, 1974) and nearby areas, and collected 132 samples in Berkeley, Hampshire, Hardy, Monroe, Morgan, Pendleton, and Pocahontas Counties, W. Va.; Augusta, Bath, Frederick, Highland, Rockingham, and Shenandoah Counties, Va.; Allegany County, Md.; and Bedford and Fulton Counties, Pa. (pl. 1, appendix). The study added a large quantity of publicly available data to evaluate the total organic carbon content and thermal maturity of Devonian shales in the area of the central and southern Appalachians denoted in figure 2. Scientists from the USGS conducted the field work, using available geologic maps from multiple State geological surveys and prior USGS mapping programs to locate Marcellus Shale and Millboro Shale exposures. One hundred twenty-eight representative outcrop samples and drill-cuttings samples from four wells of black and gray shale were collected and shipped to third-party laboratories for geochemical analyses. Low- 
temperature ash and semiquantitative major-phase mineralogy by X-ray diffraction were performed by the USGS.

\section{Description of the Study Area}

The Broadtop synclinorium is a large region of alternating synclines and anticlines in the Valley and Ridge physiographic province, extending approximately 250 miles (mi) from west-central Virginia to south-central Pennsylvania (Jacobeen and Kanes, 1974). The study area includes most of the Broadtop synclinorium and some adjacent areas from southeastern West Virginia to south-central Pennsylvania. The study area is approximately $230 \mathrm{mi}$ long in the southwest to northeast extent. The northwest-southeast width of the study area varies along its extent, but is approximately 40 mi near Pendleton County, W. Va., and Rockingham County, Va. (fig. 2; pl. 1). Northeast of the study area, the synclinorium terminates in a deep syncline containing Pennsylvanian and Mississippian strata at the surface (Jacobeen and Kanes, 1974; Dicken and others, 2005). To the southwest, the synclinorium appears to pinch out (Kulander and Dean, 1986; Dicken and others, 2005). Within the study area, stratigraphic units at the surface typically range from Lower Devonian to Upper Devonian, with thin intervals of Mississippian strata present in the core of the deepest synclines (Schultz, 1997; Dicken and others, 2005; Nicholson and others, 2005) (pls. 2, 3). In places, Silurian and older Paleozoic rocks reach the surface and partly compartmentalize the synclinorium into individual synclines separated by anticlines. The synclinorium is bordered on the northwest by the Allegheny structural front (ASF) and on the southeast by the North Mountain thrust fault, which brings Lower Paleozoic carbonates flooring the Shenandoah Valley into juxtaposition with Devonian strata (Kulander and Dean, 1986; fig. 2).

Within the Broadtop synclinorium, geologists estimated that the thickness of the Marcellus Shale ranges from 250 to 565 feet (ft) (Rader and Gathright, 2001; Rader and others, 2001; Enomoto, 2009). The range of the measurements is most likely the result of folding and faulting within the Lower to Upper Devonian shales, especially within the Valley and Ridge province. 


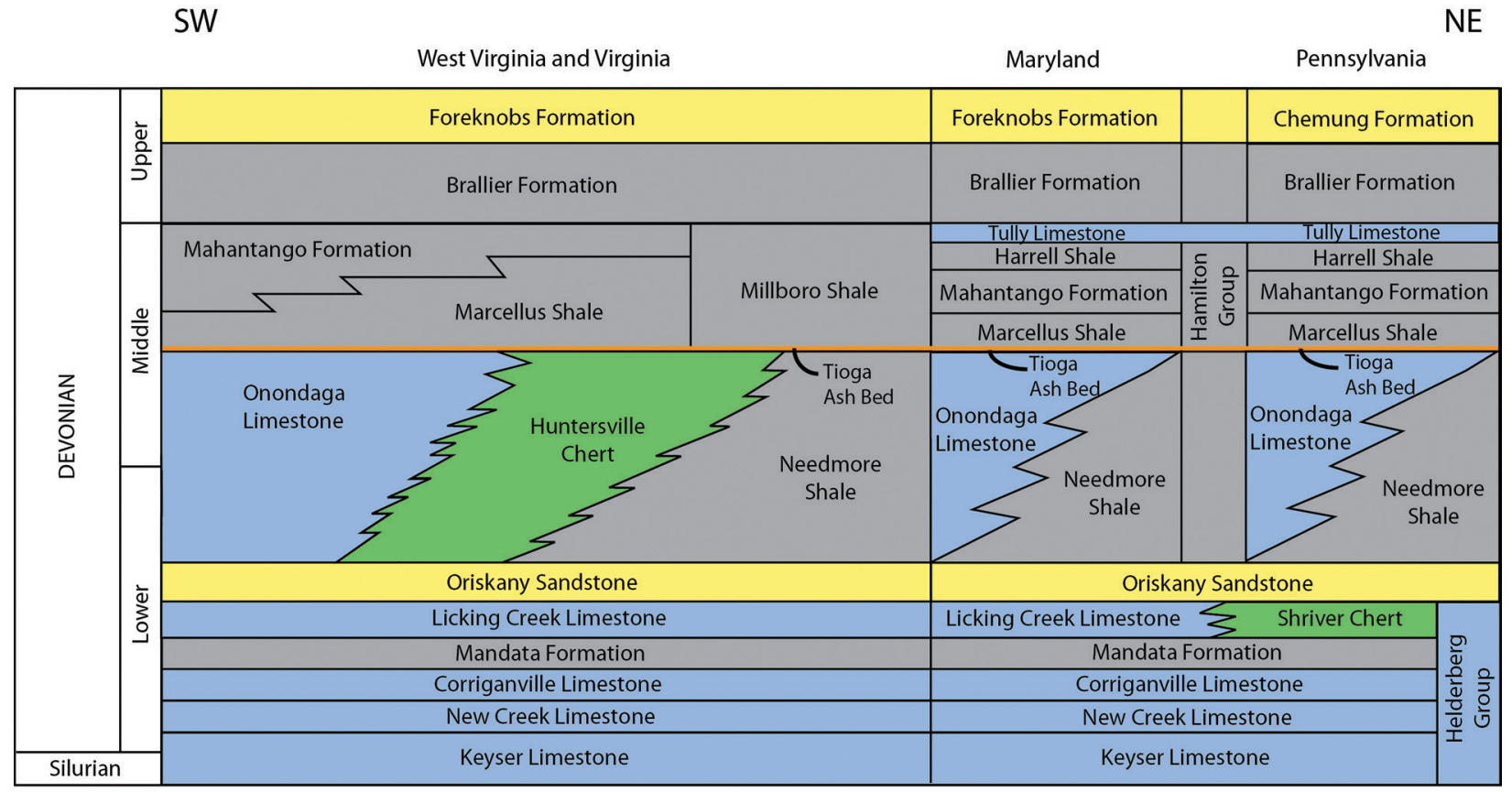

EXPLANATION
$\begin{aligned} \square & =\text { Ash bed } \\ \square & =\text { Chert } \\ \square= & \text { Limestone and (or) dolomite } \\ \square & =\text { Sandstone } \\ \square= & \text { Shale }\end{aligned}$

Figure 1. Stratigraphic column of the study area, southeastern West Virginia to south-central Pennsylvania. Modified from Kulander and Dean (1986), Woodrow and others (1988), de Witt and others (1993), Flaherty (1996), and Milici and Swezey (2006).

\section{Stratigraphy}

The stratigraphic package within the study area is composed of a Lower Paleozoic carbonatedominated interval of Cambrian to Silurian strata overlain by a predominantly siliciclastic interval of Devonian and Lower Mississippian rocks. The primary stratigraphic objectives of this study were the Lower and Middle Devonian mudstones and shales within the Needmore Shale, Marcellus Shale, and Mahantango Formation (fig. 1).

The Lower and Middle Devonian Needmore Shale (Willard, 1939) overlies the Lower Devonian Oriskany Sandstone (Vanuxem, 1839) in most of the study area where the Onondaga Limestone (Hall, 1839; Woodrow and others, 1988) and the Huntersville Chert (Woodward, 1943; Rader and Evans, 1993) are absent or indiscernable. The Needmore is a gray to dark-gray shale and silty shale, typically with subtle to distinct laminations in outcrop. The Needmore Shale is fossiliferous to occasionally fossiliferous in outcrop. A regionally extensive bentonite and chert unit, the Tioga Ash Bed (Ebright and others, 1949) is present at the top of the Needmore Shale, separating it from the Middle Devonian Marcellus Shale (Cooper, 1930). Since the Tioga is highly susceptible to weathering within the study area, it is rarely exposed. In some places in Virginia, it is thin to missing, and the Marcellus Shale appears to directly overlie the Needmore Shale. The Marcellus Shale is typically a dark-gray to black shale and contains zones of calcareous concretions and limestone beds, which appear to have some 
degree of continuity as portrayed on well logs within the area (Piotrowski and Krajewski, 1977a,b; Roen and de Witt, 1984; de Witt and others, 1993). Well-log correlations by Enomoto (2009), however, suggested that a degree of discontinuity exists in the subsurface within the Broadtop synclinorium and adjacent areas, which may have resulted from a combination of structural and depositional compartmentalization of both organic content-rich shale intervals and lower-organic-content limestone. Within the study area, the Marcellus Shale is a very dark gray to black, fissile mudstone that exhibits jointing in three directions. For example, in Highland County, Va., joint directions measuring N. $45^{\circ}$ E., N. $80^{\circ}$ E., and N. $45^{\circ} \mathrm{W}$. were observed at three outcrops of Marcellus Shale. The Marcellus Shale typically weathers to gray or brown chips. In the areas where it exhibits intraformational folding and shearing, the shale commonly exhibits pencil cleavage fracturing, and fractures with calcite and pyrite mineralization. The Marcellus Shale is distinctive in outcrop by the typical presence of concretions, high organic content, pyritic zones, and chaotic bedding and shear zones that are the result of throughgoing faults. Overlying the Marcellus Shale is the Middle Devonian Mahantango Formation (Willard, 1935), a dark-gray to gray shale and silty shale. The Mahantango Formation grades upward with apparent conformity from the upper Marcellus Shale into the overlying Upper Devonian Brallier Formation (Butts, 1918; fig. 1). In eastern West Virginia and Virginia, the Mahantango Formation cannot be differentiated from the Marcellus Shale, and the two formations are mapped collectively as the Millboro Shale (Butts, 1940; Rader and Evans, 1993). In New York, Pennsylvania, and western Maryland, the formations between the Onondaga Limestone and the Tully Limestone, including the Marcellus Shale and the Mahantango Formation, are collectively named the Hamilton Group (Cooper, 1930; de Witt and others, 1993).

In some areas of Pennsylvania, a thin dark-gray shale overlies the Mahantango Formation. It is named the Harrell Shale (Butts, 1918; Swartz, 1939). The Harrell Shale is not present in the entire study area. In most of the study area, the top of the Mahantango Formation is considered to be the base of the lowest siltstone bed that forms the base of the Brallier Formation (Rader and Evans, 1993). The Brallier Formation extends upward to the base of the Upper Devonian Chemung Formation (Hall, 1839), which now is designated the Foreknobs Formation in West Virginia, Virginia, and Maryland (Dennison, 1970; Rader and Evans, 1993). 


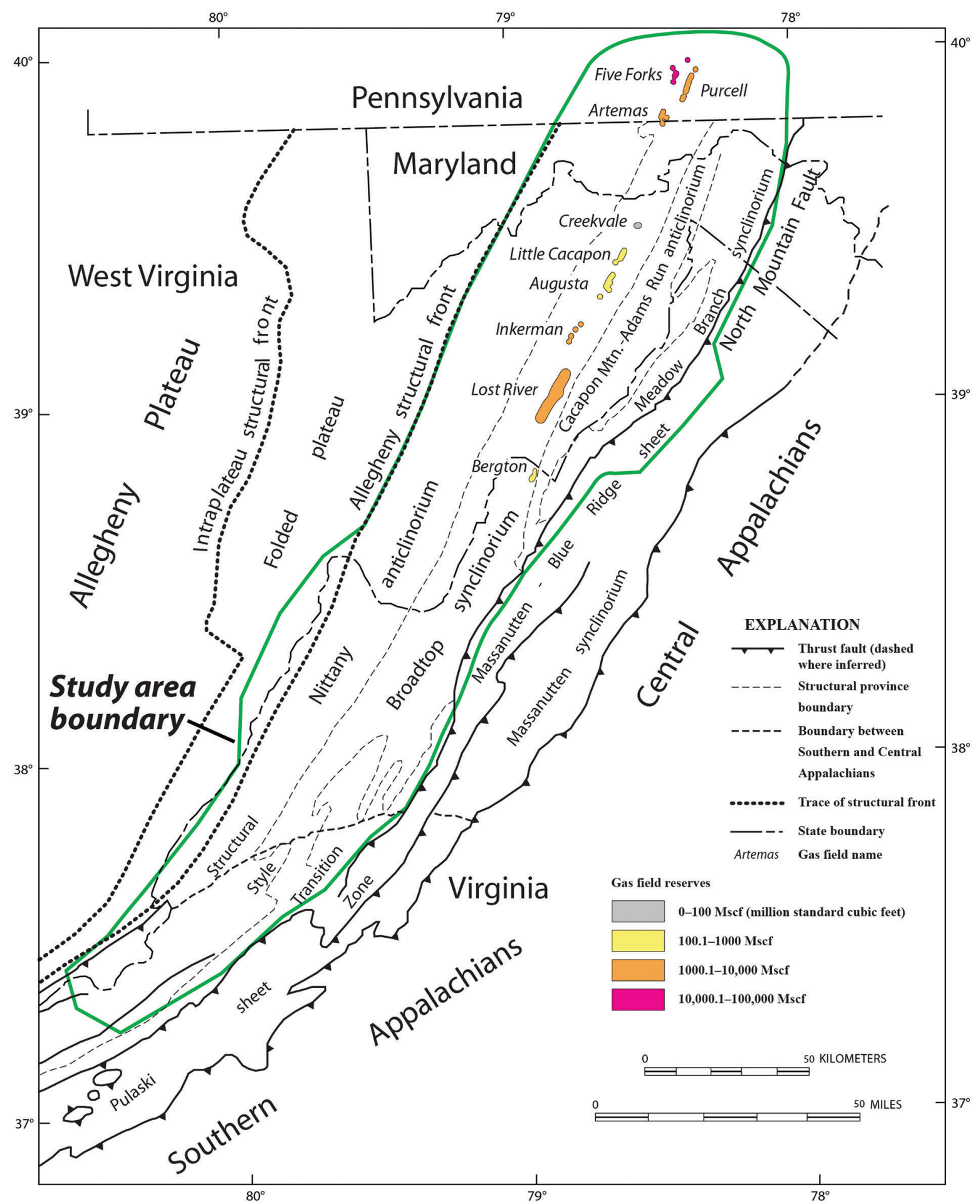

Figure 2. Map of major structural features, the study area of this report (outlined in green), and natural gas fields in the vicinity of the study area. Modified from Kulander and Dean (1986, fig. 1 (AAPG॰1986; used by permission of the American Association of Petroleum Geologists, whose permission is required for further use)), Milici (1990), and Energy Information Administration (2005). The Energy Information Administration (2005) assigned gas fields to classes based on proven gross natural gas reserves in 2001. 


\section{Structural Geology}

The study area outline on plates 1, 4, and 5 illustrates the geographic extent of this study, and the plates show the distribution of the Hamilton Group, Marcellus Shale, Millboro Shale, and Needmore Shale as digitally compiled by Nicholson and others (2005) and Dicken and others (2005). The morphology of the outcrop belt illustrates the complexity of the tectonic structures that compose the Valley and Ridge physiographic province. Also shown on plates 1, 4, and 5 are the locations of two of the structural cross sections published by Kulander and Dean (1986). Plates 2 and 3 include portions of Kulander and Dean's (1986) cross sections 1 and 5, on which are illustrated the major anticlinoria and synclinoria, thrust faults, and thrust sheets of the Valley and Ridge province in the central Appalachians.

Nickelsen (1963) defined folds within the Ordovician and Devonian strata in central Pennsylvania having wavelengths between 7 and $10 \mathrm{mi}$ as "first order folds," folds having wavelengths between 1.5 and $2 \mathrm{mi}$ as "second order folds," folds having wavelengths less than $0.5 \mathrm{mi}$ as "third order folds," and folds of outcrop size having wavelengths of several tens of feet as "fourth order folds." Nickelsen (1963) recognized that the limits of fold-size classes were related to thicknesses of lithic units and competent members, that the fold-size-class limits were arbitrary, and that it was likely that the fold sizes occur on a continuum. In this study of the Broadtop synclinorium, third and fourth order folds were observed in outcrop in the Middle Devonian strata. Kulander and Dean (1986) (pls. 2, 3) and Schultz (1997) recognized the presence of third and fourth order folds, thrust faults, and ductile structures in Silurian and Devonian shales above Ordovician carbonate strata that had been folded into second order anticlines and synclines. Examples of third and fourth order folds are illustrated in Jacobeen and Kanes (1974, figs. 4, 5), Pohn and others (1985, figs. 3, 5, 6), and Schultz (1997, figs. 3$5,6-12)$.

\section{Previous Work}

The Broadtop synclinorium of Virginia, West Virginia, Maryland, and southern Pennsylvania has been studied by geologists over many years. Local, county-level and quadrangle-scale surveys include those by Darton (1896, 1899), O'Harra (1900), Stose and Swartz (1912), Tilton and others (1927), Berryhill and others (1956), and de Witt and Colton (1964), which provided initial descriptions of the local geology. Detailed structural studies include those by Pohn and others (1985) and Schultz (1997). Regional structural studies include, among others, those by Rowlands and Kanes (1972), Jacobeen and Kanes (1974, 1975), Kulander and Dean (1986), and Dunne (1996). Dicken and others (2005) and Nicholson and others (2005) developed digital geologic map shapefiles from published State geologic maps; polygons from these shapefiles were used in developing the reconnaissance-scale field maps and in depicting the location and distribution of data in this report (pls. 1, 4, 5). Field mapping by geologists from the USGS, the West Virginia Geological and Economic Survey, and the Virginia Division of Geology and Mineral Resources continues to contribute to an improved understanding of the synclinorium. Where available, unpublished maps from these ongoing projects were used in locating outcrops for sampling and confirming formation identity.

Stratigraphic summaries of Devonian strata include those by Dennison (1971), Woodrow and others (1988), Hasson and Dennison (1988), and Roen and Kepferle (1993). Dennison (2005) presented an overview of the outcrop work he and his students accomplished over several decades, with a long list of publications given at the end of his field trip guidebook. Ryder and others $(2008,2009)$ illustrated the structural and stratigraphic content and context of the Devonian strata of the central Appalachians, including within the study area, in detailed cross-section format. 
Biostratigraphic and thermal maturity studies for the area have been published by Harris and others (1994) and Repetski and others (2008). Their work concluded that the Devonian black shales are within the thermal maturity "window" of gas generation and preservation within the study area.

Enomoto (2009) presented work relevant to the study area completed through the USGS National Coal Resources Database System cooperative funding program with the Virginia Division of Geology and Mineral Resources. This research reviewed the stratigraphic and organic geochemistry content of the Millboro Shale in the Broadtop synclinorium in Highland and Rockingham Counties, Va., and suggested that the Millboro Shale has an organic richness sufficient to have generated hydrocarbons.

\section{Exploration and Production History of the Area}

Petroleum exploration in the 1950s and 1960s led to the discovery of several gas fields within the study area (Energy Information Administration, 2005) (fig. 2; pl. 1). In southern Pennsylvania, natural gas was discovered in the Lower Devonian Oriskany Sandstone in the Purcell, Five Forks, and Artemas fields in 1957, 1962, and 1963, respectively. These fields were abandoned in 1974, 1972, and 1972, respectively (possibly because further production was uneconomical), after cumulative production of almost 21 billion standard cubic feet (Bscf) of gas from the Oriskany Sandstone (Harper and Patchen, 1996).

In Hampshire and Hardy Counties in eastern West Virginia, there is a northeast-southwesttrending line of gas fields that also produced from the Oriskany Sandstone. They include the Creekvale (Gore), Little Cacapon, Augusta, Inkerman, and Lost River fields. The Creekvale (Gore) discovery consisted of two successful wells that were completed, but there are no cumulative production data available (Cardwell, 1982). Little Cacapon field, discovered in 1965, produced about 1 Bscf of gas. In 1971, the field was converted to a gas storage facility (Cardwell, 1982). The Augusta field produced 1 Bscf of gas from 1953 to 1971 before it, too, was converted to a gas storage facility (Cardwell, 1982). The Inkerman (Whip Cove West) field produced 4.8 Bscf from 1966 to 1973 and the Lost River (Whip Cove East) field produced 9.1 Bscf from 1962 to 1973 (Cardwell, 1981; Cardwell and Avary, 1982).

In western Virginia, the Bergton field was discovered in 1935; it lies at the southwestern end of this series of Oriskany Sandstone fields. Several drilling campaigns took place between 1935 and 1980, when a pipeline was built and connected to a nearby interstate pipeline system to establish commercial production. The last reported production from Rockingham County, where the Bergton field is located, was in 1986. During two periods of production, the field produced slightly over 200 million standard cubic feet (Mscf) of gas (Milici, 1990).

\section{Sampling and Analysis}

The distribution of sample data is displayed on plates 1, 4, and 5. Outcrop samples were collected from exposures throughout the study area, from Monroe County in southeastern West Virginia to Bedford County in southern Pennsylvania. Outcrop samples were collected throughout the study area at localities that presented opportunities for reasonably fresh samples. Where major highways transect the study area, opportunities to put outcrop data into context with the regional structural profiles of Kulander and Dean (1986) were used. Two of their profiles, (section 1, shown on plate 2, and section 5, shown on plate 3 ) are included with this report to show the overall structural style of the Broadtop synclinorium in the vicinity of a number of sample localities. The northern profile, shown on plate 2, traverses the Broadtop synclinorium in western Maryland and northeastern West Virginia. North of Bedford and Fulton Counties, Pa., access to unweathered outcrops became scarce, resulting in few 
sample collecting locations (pl. 1). The southern profile, shown on plate 3, traverses the Broadtop synclinorium in western Virginia.

In an effort to evaluate more fully the oil and gas resource potential of the George Washington National Forest and to compare the thermal stress levels of Middle Devonian shale east of the Broadtop synclinorium, four samples were taken from the Massanutten synclinorium (fig. 2; pl. 1). The Massanutten synclinorium is approximately $10 \mathrm{mi}$ to the east of the Broadtop synclinorium, and represents the easternmost exposure of Devonian sedimentary strata in Virginia. Marcellus Shale is exposed in the core of the Massanutten synclinorium (Rader and Biggs, 1976).

Using available geologic quadrangle and county maps and remote sensing images, the authors identified potential outcrops displaying reasonably fresh exposures of Lower and Middle Devonian shale. There is a strong relationship between color and organic carbon content. In their study of Devonian shales in the Appalachian basin, Hosterman and Whitlow (1983) compared the color of dry pressed-powder wafers as designated from the Munsell soil color charts (Munsell Color Company, 1954) to organic carbon content of about 880 samples from 50 drill holes, and found that the majority of the samples that were very dark gray to black in color contained greater than 7 percent organic carbon. At outcrops that yielded reasonably fresh samples of black or dark-gray shale, as fresh a sample as possible was collected by digging as far into the outcrop as possible with hand picks and shovels. The sample was collected and, in most cases, numbered sequentially by order of collection with an alphabetic prefix indicative of the topographic quadrangle name (for example, AG01 is the first sample collected in the Augusta Springs quadrangle). A deviation from this naming scheme applies to 20 samples collected in the McDowell quadrangle, Highland County, Va., where the samples are labeled US250-01 through -20. Other labels that deviate from this naming method are three samples from the Waiteville quadrangle, Monroe County, W.Va. (MN-01, MN-02, and MN-03). Strike, dip, and global positioning system (GPS) location were recorded for each outcrop sample collected. Additionally, drill cuttings from four wells (HI-0001, HI-0003, RO-0016, and RO-0024) were sampled; these samples were given the well number designation which reflects the county where the wells were drilled. Fourteen samples collected by collaborators are indicated with a YY99 prefix (appendix).

The outcrop samples were air dried and crushed to less than 1 centimeter $(\mathrm{cm})$ top-size with a jaw crusher before splitting for analysis. One split was submitted for geochemical analysis and the other retained by the USGS for determination of low-temperature ash and semiquantitative mineralogy. GeoMark Research \& Core Laboratories, Houston, Tex., and Humble Geochemical ServicesWeatherford Laboratories, Houston, Tex., were contracted to conduct source-rock analyses (total organic carbon (TOC), in weight percent; Rock-Eval pyrolysis; and thermal maturity testing, reported as average reflectance $\left.\left(\% \mathrm{R}_{\mathrm{o}}\right)\right)$. These data were supplied to the authors for interpretation in conjunction with their outcrop observations. The organic geochemical data are presented in the appendix along with pertinent outcrop and geographic data.

Dulong analyzed the whole-rock semiquantitative mineralogy of 106 outcrop samples using Xray diffraction equipment. Splits of the samples for mineralogy were ground to less than 200 mesh (73 microns $(\mu \mathrm{m})$ ) in a Retsch mill, dried at $100{ }^{\circ} \mathrm{C}$, low temperature ashed with a LFE Corporation LTA504 oxygen plasma asher, and prepared as a 25 -millimeter $(\mathrm{mm})$ pellet for X-ray diffraction (Pontolillo and Stanton, 1994). A Scintag X1 X-ray diffractometer was used to scan the sample from $3^{\circ}$ to $65^{\circ}$ twotheta, counting for 2.5 seconds every $0.02^{\circ}$ two-theta, with copper radiation produced with 45 kilovolts and 40 milliamps. A computer program was used to process the X-ray spectrum and estimate the proportions of major mineral phases (Hosterman and Dulong, 1989). The kaolinite and chlorite peaks at high $24^{\circ}$ and low $25^{\circ}$ two-theta respectively were examined graphically, and computations were made from the raw-counts-per-second spectral data to estimate their fractional concentrations (Biscaye, 1964). 
Dulong reported the sum of potassium feldspar and plagioclase in the feldspar content; calcite, siderite, dolomite, and ankerite in the carbonate content; illite and illite-smectite mixed clays in the illite fraction; illite, illite-smectitie mixed clays, chlorite, and kaolinite in the summed clay fraction; and pyrite, marcasite, and sphalerite in the pyrite fraction. Minerals other than these that were identified were classified as "other." Values of " 0 " indicate the mineral was not detected. The whole-rock mineralogy was not normalized to 100 percent, but the reported constituency ranged from 91 to 102 percent (due to rounding of values). The semiquantitative mineralogy is provided in the appendix.

\section{Discussion of Data}

In total, 10 samples were collected from the Needmore Shale; 108 samples were collected from the Marcellus Shale or what was interpreted to be Marcellus Shale (including 4 samples collected from well drill cuttings within the Marcellus Shale, and 2 samples collected from bentonite beds within the Marcellus Shale); 8 samples were collected from the Mahantango Formation; 1 sample was collected from the Harrell Shale; 1 sample was collected from the Keyser Limestone; 1 sample was collected from the Tioga Ash Bed; and 1 sample was collected from a dark-gray shale identified as the Lower Devonian Mandata Formation of the Helderberg Group (Swartz, 1939) (fig. 1; pl. 1; appendix). Two samples were labeled "Unknown" as it could not be determined what formation was sampled.

Outcrops of the Needmore Shale and Mahantango Formation typically showed minimal structural disturbance other than minor faulting and the development of a regional fracture network. On the other hand, outcrops of the Marcellus Shale (or Millboro Shale if undifferentiated from the Mahantango Formation) typically showed substantial structural disruption, so that in many cases the outcrop was faulted, fractured, sheared, or a combination of all three. Of note, though, those zones which contained limestones or calcareous shales typically were not disrupted by throughgoing faults, but often exhibited well-developed joint systems.

\section{Geochemistry}

The organic richness of the analyzed samples, measured in TOC weight percent, is shown on plate 4 and summarized in table 1 and figures $3 A-C$. These are present-day TOC values, and the values may have been much higher when these rocks were immature. The average of the TOC values for the Marcellus Shale samples in their current state is greater than 2 percent, with a maximum value of over 7 percent. The TOC content of the samples collected in the Harrell Shale and Mandata Formation was about 2.5 percent and 3.5 percent, respectively. The average of the TOC weight-percent values of the Needmore Shale samples was slightly greater than 1 percent, but had a maximum value greater than 3.8 percent. The average TOC content of the Mahantango Formation samples did not exceed the accepted richness threshold for a hydrocarbon source rock of 1 percent (Dow, 1977, 1978; Law, 1999; Peters and Moldowan, 1993; Peters and others, 2005; Tissot and Welte, 1984).

Table 1. Total organic carbon content, in weight percent, of samples analyzed for this study.

[TOC, total organic carbon]

\begin{tabular}{lcccc}
\hline \multicolumn{1}{c}{ Stratigraphic unit } & Number of samples & Minimum TOC & Average TOC & Maximum TOC \\
\hline Mahantango Formation & 7 & 0.19 & 0.57 & 1 \\
Marcellus Shale & 94 & 0.17 & 2.11 & 7.22 \\
Needmore Shale & 10 & 0.19 & 1.02 & 3.84 \\
\hline
\end{tabular}



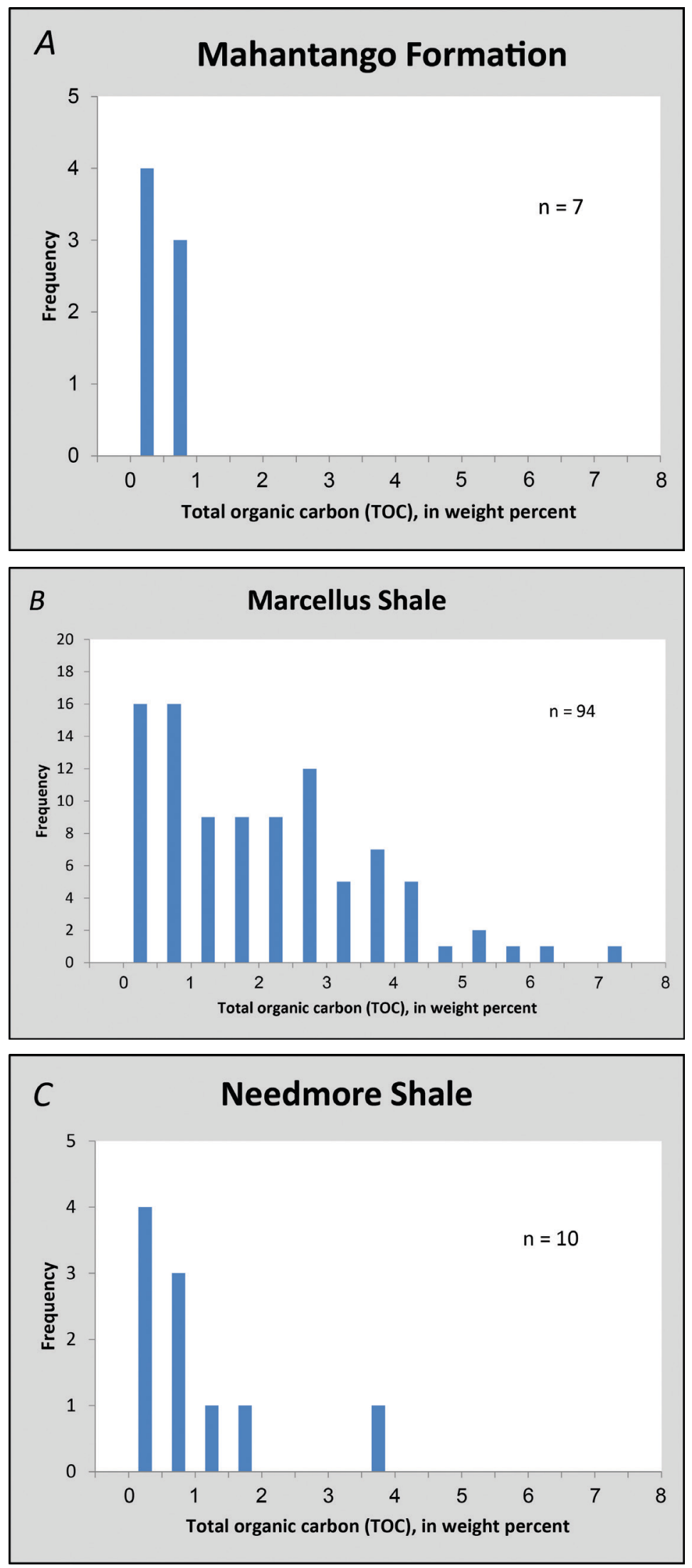

Figure 3. Bin-frequency plots of total organic carbon (TOC) content, in weight percent, of $A, 7$ Mahantango Formation outcrop samples; $B, 94$ Marcellus Shale outcrop and drill-cuttings samples; and $C$, 10 Needmore Shale outcrop samples, all analyzed for this study. Bins are in 0.5 weight-percent increments. n, number of samples. 
The current-day thermal stress (that is, thermal maturity, reported as average reflectance, $\% R_{0}$ ) of the study area samples shows that, for the most part, all of the samples are within the thermal stress zones equivalent to the wet gas generation and dry gas generation. According to Dow (1977) and Dembicki (2009), the hydrocarbon generation stages for oil-prone kerogens are as follows:

$$
\begin{aligned}
& \% \mathrm{R}_{\mathrm{o}}=0.0-0.6=\text { immature generation thermal levels } \\
& \% \mathrm{R}_{\mathrm{o}}=0.6-1.35=\text { oil generation thermal levels } \\
& \% \mathrm{R}_{\mathrm{o}}=1.35-2.0=\text { wet gas generation thermal levels } \\
& \% \mathrm{R}_{\mathrm{o}}=2.0-3.0=\text { dry gas generation thermal levels }
\end{aligned}
$$

The thermal stress values of the samples analyzed are shown on plate 5, and summarized in table 2 and figures $4 A-C$. According to Repetski and others (2008), all but three outcrop samples in this study were collected in areas east of the Devonian $2.0 \% \mathrm{R}_{\mathrm{o}}$ isograd, and all but one were collected east of the Devonian 3.0 conodont color alteration index (CAI) isograd in their study. This observation indicated that the Devonian strata in the study area are within the "gas window," greater than $1.35 \% \mathrm{R}_{0}$, and greater than 2.5 conodont CAI (Repetski and others, 2008). With the exception of five samples from the Marcellus Shale which had $\% \mathrm{R}_{\mathrm{o}}$ values within the "oil window" (between $\% \mathrm{R}_{\mathrm{o}}=0.6$ and 1.35; see appendix), all other samples had values in the "gas window" above $1.35 \% \mathrm{R}_{\mathrm{o}}$, including some samples with greater than $3.0 \% \mathrm{R}_{\mathrm{o}}$. It is possible that the measurements for the five samples with less than 1.35 $\% \mathrm{R}_{\mathrm{o}}$ were made on re-migrated solid hydrocarbons. Also, according to Hackley and others (2013), most of the reflectance measurements, especially the ones above $1.35 \% \mathrm{R}_{0}$, likely were made on solid bitumen/pyrobitumen and not vitrinite. In this report, then, the term "reflectance" will indicate the averaged measurements made on the organic matter in the samples as reported by the third-party laboratories.

A general increase in thermal maturity or average reflectance from southwest to northeast can be inferred from the data displayed on plate 5. This is the direction of increased sedimentary thickening in the basin, so this increase is expected. The general trend is supported by regional data and trends from Repetski and others (2008).

Table 2. Average reflectance $\left(\% R_{0}\right)$ values of samples analyzed for this study.

\begin{tabular}{lcccc}
\hline \multicolumn{1}{c}{ Stratigraphic unit } & Number of samples & Minimum \% & Average $\% \mathbf{R}_{\mathbf{o}}$ & Maximum \% \\
\hline Mahantango Formation & 6 & 2.45 & 2.89 & 3.44 \\
Marcellus Shale & 97 & 0.74 & 2.56 & 3.43 \\
Needmore Shale & 7 & 1.42 & 2.33 & 3.13 \\
\hline
\end{tabular}



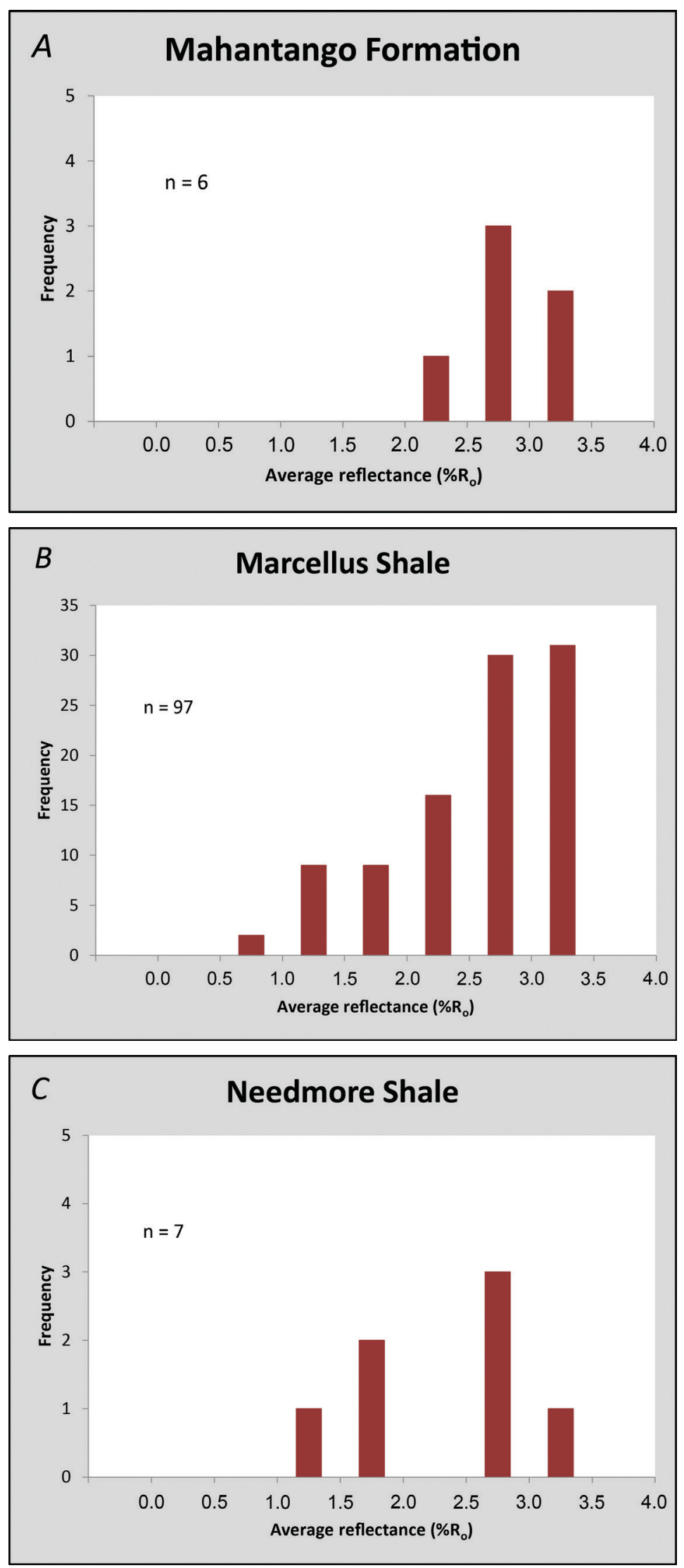

Figure 4. Bin-frequency plots of the average reflectance $\left(\% \mathrm{R}_{0}\right)$ values of $A, 6$ Mahantango Formation outcrop samples; $B, 97$ Marcellus Shale outcrop and drillcuttings samples; and C, 7 Needmore Shale outcrop samples, all analyzed for this study. Bins are in $0.5 \% R_{0}$ increments. $\mathrm{n}$, number of samples. 
During the initial stages of the fieldwork, the authors discussed if faulting within the shale would locally elevate the recorded thermal stress. Where possible, samples were taken to investigate this hypothesis. In the appendix, the column labeled "sheared" indicates whether the samples were collected from a zone with shear features by having " 1 " for an affirmative and " 0 " for a negative observation.

During the sampling process, effort was made to collect samples of the Marcellus Shale in zones that were undeformed, and in zones that were obviously sheared and deformed. Of the 102 shale samples collected from outcrop determined to be Marcellus Shale, 25 were collected in zones interpreted to be sheared and 77 were collected in zones interpreted to be less deformed. Cross-plots of non-sheared and sheared samples versus average reflectance, TOC, and bulk-sample chlorite content are shown in figures 5 through 7, respectively, for those samples analyzed for each property. Comparison of thermal maturity versus shearing proved the null hypothesis, showing no significant elevation in thermal maturity of sheared samples. Comparison of TOC content with shearing showed an elevated TOC in the samples collected in the sheared zones. Comparison of the chlorite content versus shearing showed a reduced amount of chlorite in the samples collected in the sheared zones.

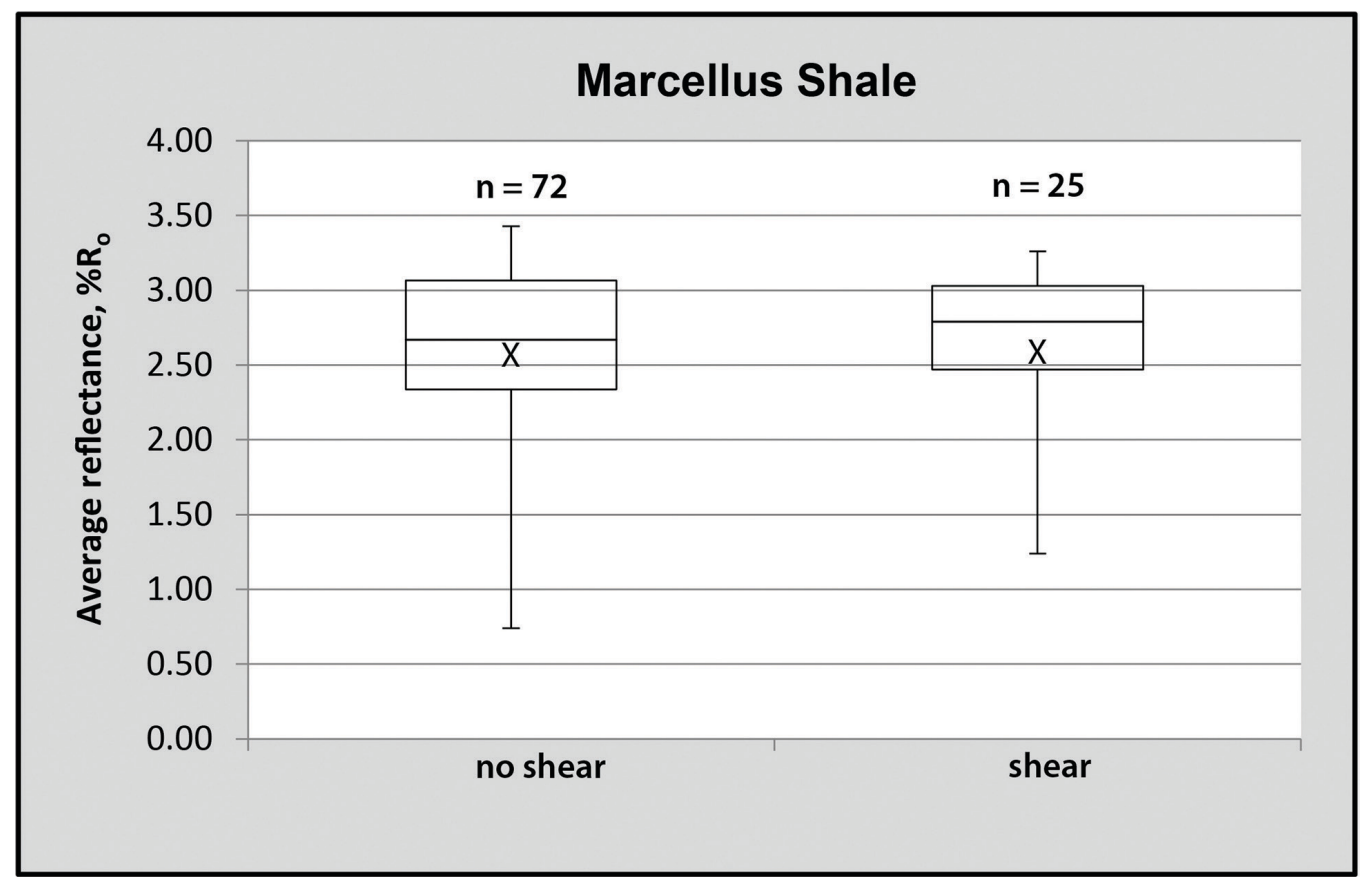

Figure 5. Box-and-whisker plot of no shear and shear versus average reflectance $\left(\% \mathrm{R}_{0}\right)$ of Marcellus Shale outcrop samples analyzed for this study. The central line in the boxes is the median value of average reflectance; the top and bottom edges of the boxes indicate the 25th and 75th percentiles, respectively. The whiskers indicate the minimum and maximum average reflectance values; the crosses $(X)$ represent the mean. $n$, number of samples. 


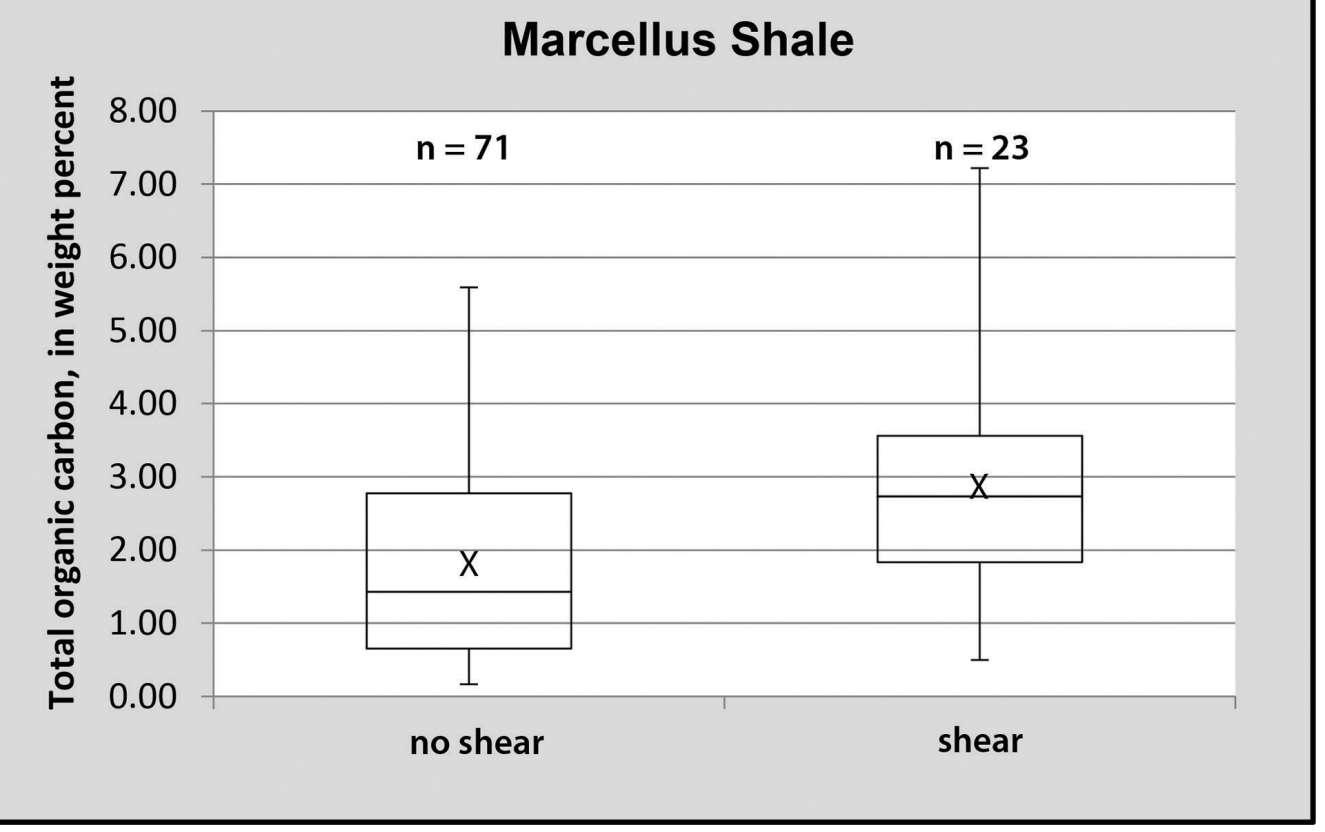

Figure 6. Box-and-whisker plot of no shear and shear versus total organic carbon (TOC) content, in weight percent, of Marcellus Shale samples analyzed for this study. The central line in the boxes is the median value of TOC; the top and bottom edges of the boxes indicate the 25th and 75th percentiles, respectively. The whiskers indicate the minimum and maximum TOC values; the crosses $(X)$ represent the mean. $n$, number of samples.

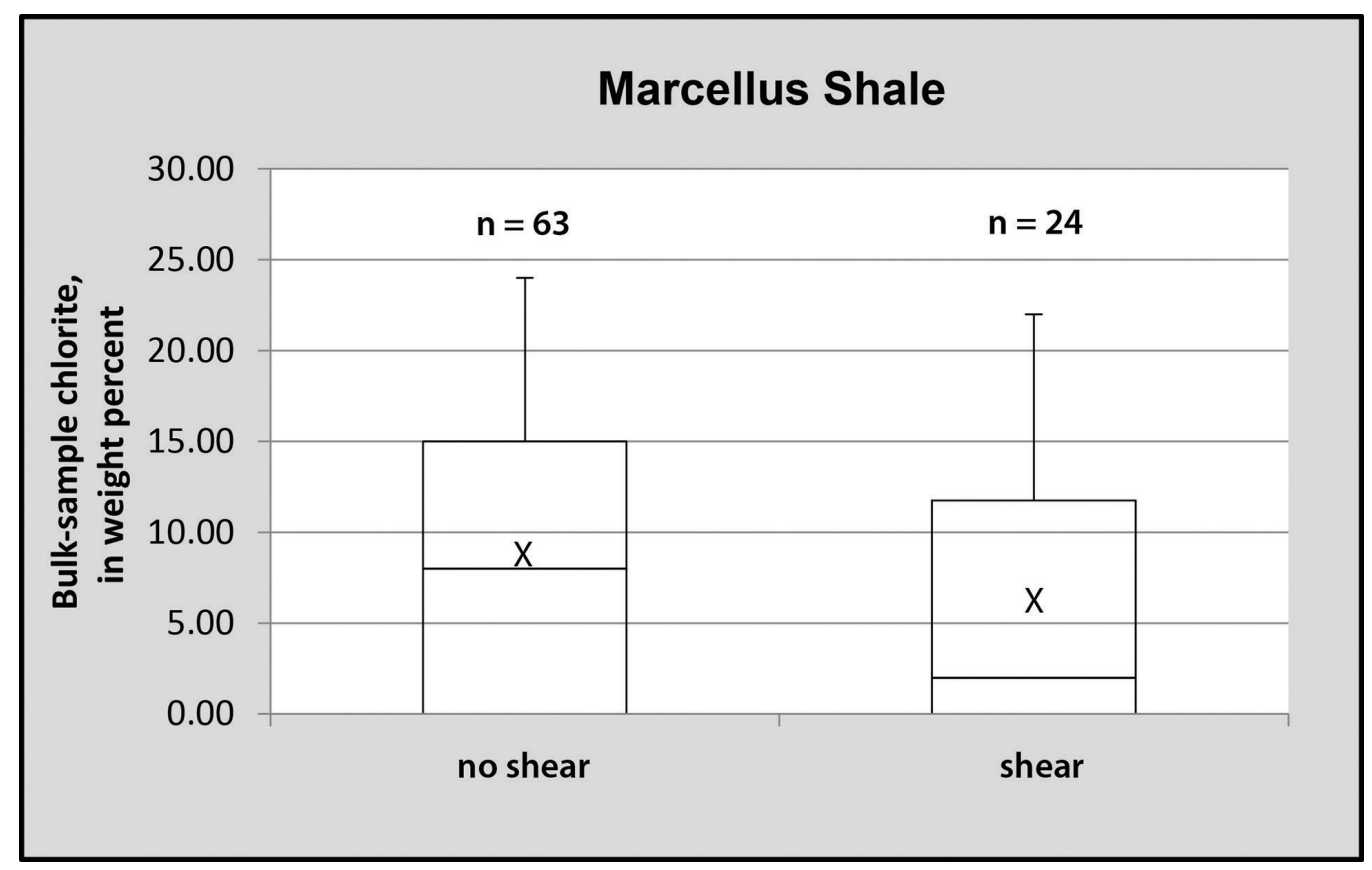

Figure 7. Box-and-whisker plot of no shear and shear versus bulk-sample chlorite content, in weight percent, of Marcellus Shale samples analyzed for this study. The central line in the boxes is the median value of chlorite content; the top and bottom edges of the boxes indicate the 25th and 75th percentiles, respectively. The whiskers indicate the minimum and maximum chlorite content values; the crosses $(X)$ represent the mean. $n$, number of samples. 


\section{Mineralogy}

The whole-rock semiquantitative major-phase mineralogy results of the Mahantango Formation, Marcellus Shale, and Needmore Shale outcrop samples are summarized in figures $8 A-C$. The quartz content of the Mahantango Formation samples ranged from 29 to 45 percent, with an average of 41 percent. This is similar for the Needmore Shale samples, for which the quartz content range was 31 to 53 percent, with an average of 42 percent. The Marcellus Shale samples contained a minimum of 21 percent quartz and a maximum of 77 percent, averaging 49 percent.

In this study, there were differences among the formations in the carbonate fraction and clay content. In the Mahantango Formation and Needmore Shale samples, the average carbonate fractions were 3 percent and 0.5 percent, respectively. In the Marcellus Shale samples, the average carbonate content was 5 percent, with a range of 0 to 60 percent. The total clay content, calculated by summing the illite, illite-smectite mixed clay, kaolinite, and chlorite fractions, averaged 48 percent and 49 percent in the Mahantango Formation and Needmore Shale, respectively. In the Marcellus Shale samples, the average clay content was 38 percent, with a range of 16 to 60 percent. The Marcellus Shale samples in this study contained an average of 8 percent chlorite, 29 percent illite and illite-smectite mixed-layer clays, and 1 percent kaolinite.

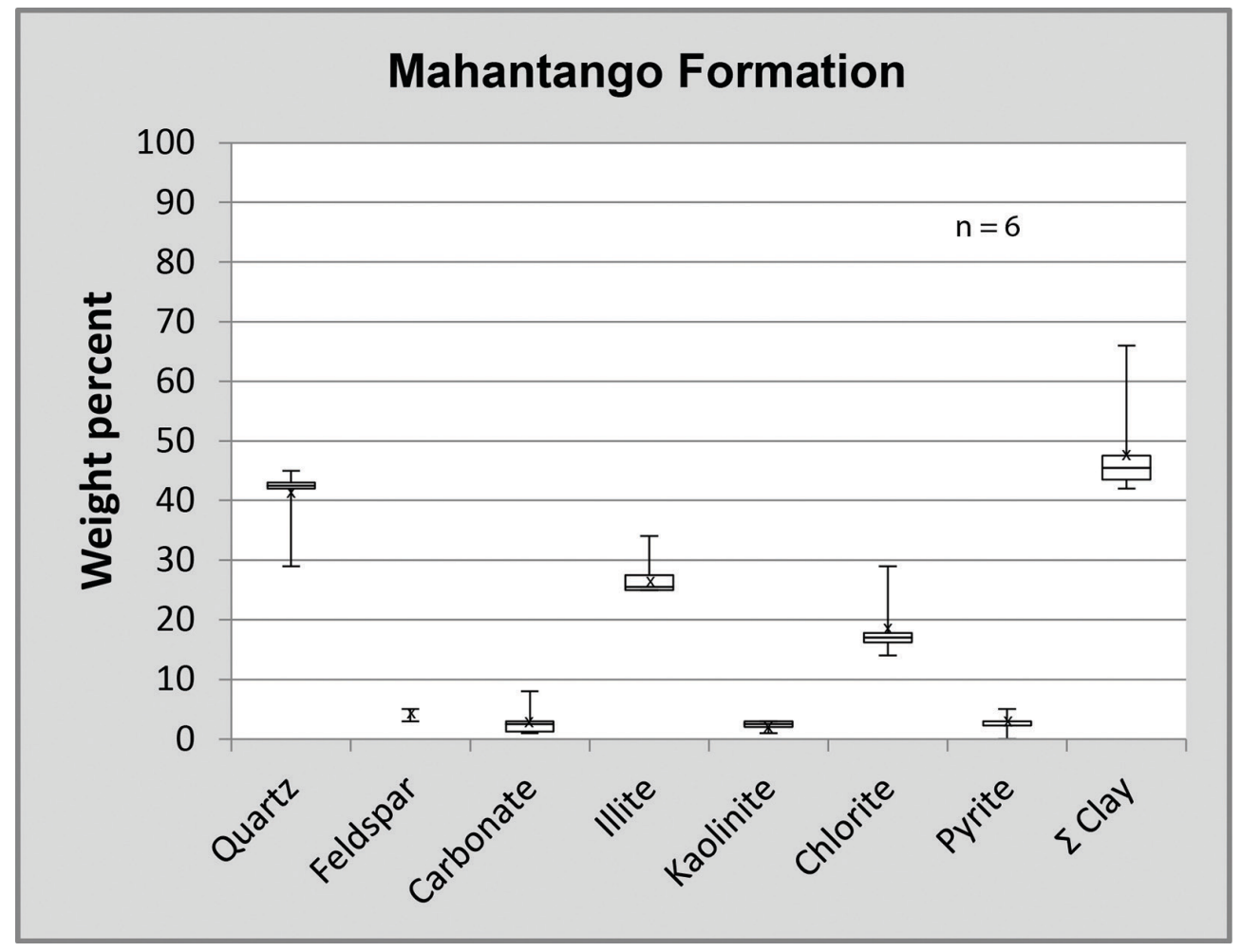

Figure 8A. Box-and-whisker plot showing the semiquantitative mineralogy, in weight percent, of 6 Mahantango Formation outcrop samples analyzed for this study. The central line in the boxes is the median value of each mineral; the top and bottom edges of the boxes indicate the 25th and 75th percentiles, respectively. The whiskers indicate the minimum and maximum values; the crosses $(X)$ represent the mean. $n$, number of samples; $\Sigma$ Clay, total clay content, calculated by summing the illite, illite-smectite mixed clay, kaolinite, and chlorite fractions. 
Finally, the maximum pyrite content of 14 percent by weight in the Marcellus Shale samples in this study exceeds the maximum pyrite content of the Mahantango Formation and Needmore Shale samples of 5 percent and 4 percent, respectively. The average of 2 percent pyrite for the Marcellus Shale samples is similar to the averages of the Mahantango Formation and Needmore Shale samples, which were 3 percent and 1 percent, respectively.

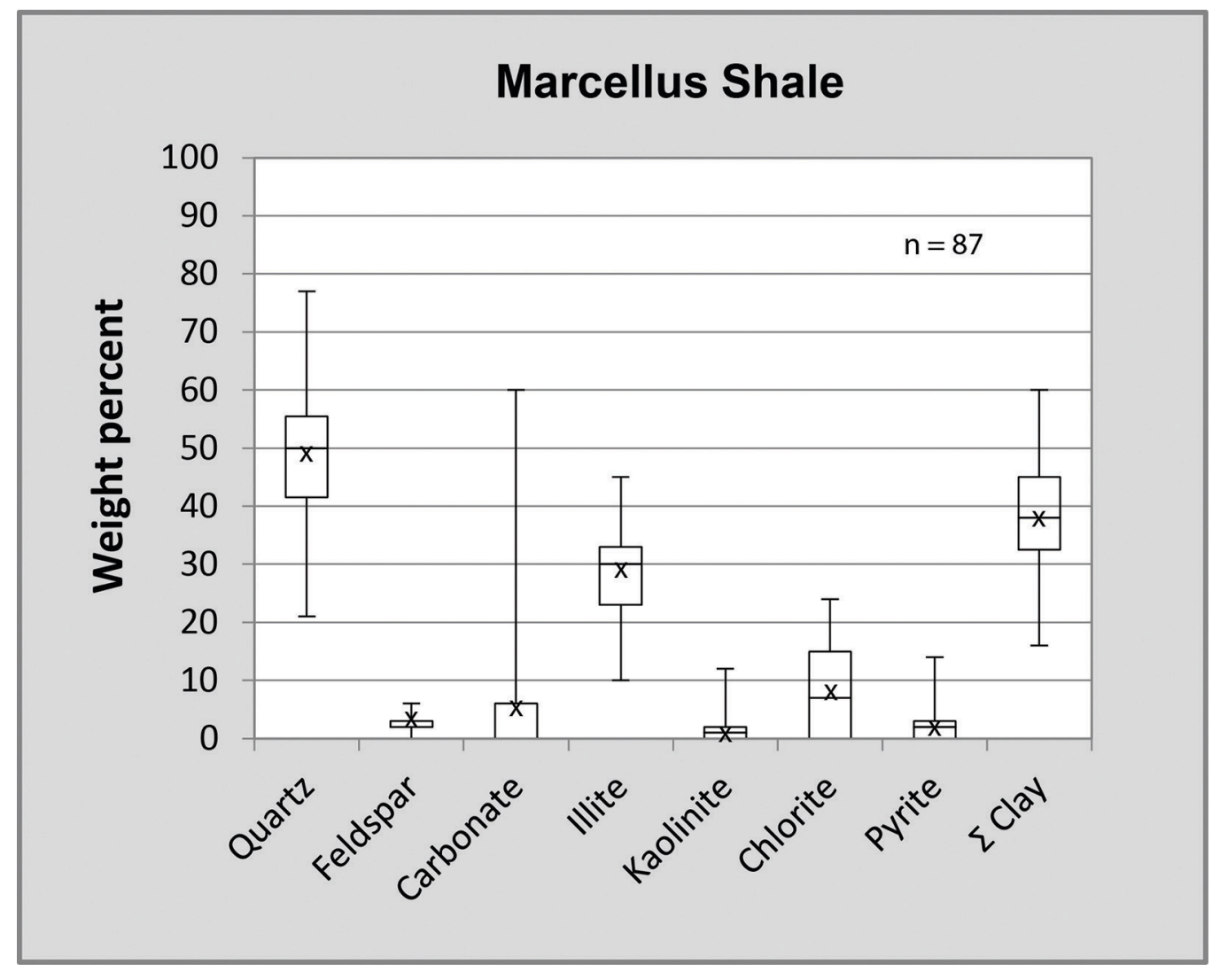

Figure 8B. Box-and-whisker plot showing the semiquantitative mineralogy, in weight percent, of 87 Marcellus Shale outcrop samples analyzed for this study. The central line in the boxes is the median value of each mineral; the top and bottom edges of the boxes indicate the 25th and 75 th percentiles, respectively. The whiskers indicate the minimum and maximum values; the crosses $(X)$ represent the mean. $n$, number of sample; $\Sigma$ Clay, total clay content, calculated by summing the illite, illite-smectite mixed clay, kaolinite, and chlorite fractions. 


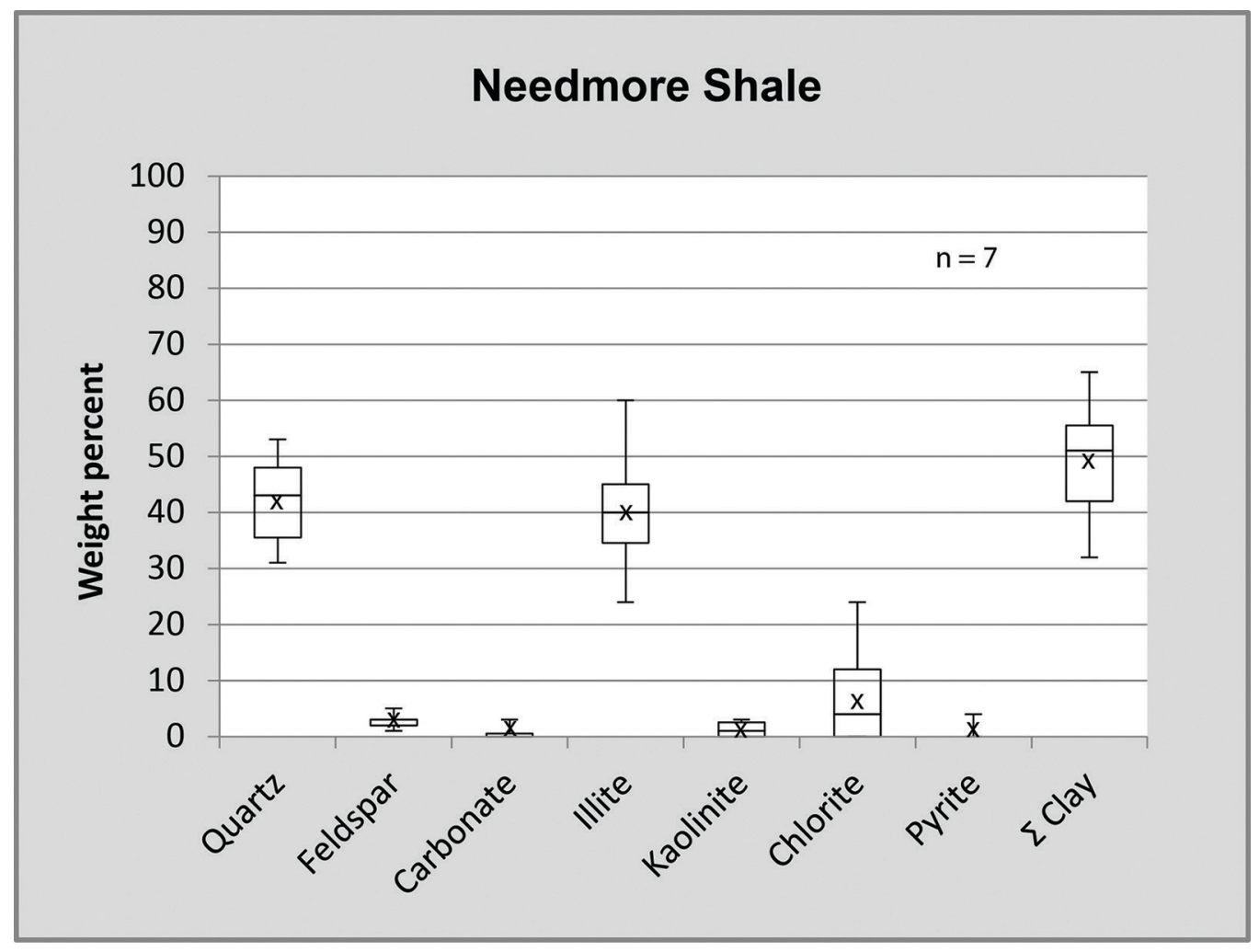

Figure 8C. Box-and-whisker plot showing the semiquantitative mineralogy, in weight percent, of 7 Needmore Shale outcrop samples analyzed for this study. The central line in the boxes is the median value of each mineral; the top and bottom edges of the boxes indicate the 25th and 75th percentiles, respectively. The whiskers indicate the minimum and maximum values; the crosses $(X)$ represent the mean. $n$, number of samples; $\Sigma$ Clay, total clay content, calculated by summing the illite, illite-smectite mixed clay, kaolinite, and chlorite fractions.

\section{Interpretation of Data}

The TOC content of the drill-cuttings sample from the Whetzel \#1 well (the only cuttings sample with TOC), 3.23 percent, is within the range of TOC values for the outcrop samples of Marcellus Shale, but above the average of 2.11 percent. The range of TOC content in the Marcellus Shale samples from the study area may reflect the degradation of organic material by surface and near-surface weathering, and the depletion of organic material by the conversion of kerogen to hydrocarbons and their expulsion from the source rock (Dembicki, 2009). The outcrop sampling procedures employed during this study resulted in the collection of as fresh a set of samples as was realistically possible. Slightly higher TOC content was reported in Wang and Carr (2012b), in which the median value measured in 195 Marcellus Shale core samples collected in 18 wells in southwestern Pennsylvania and northern West Virginia was about 5 percent. The maximum TOC value measured in those samples was almost 20 percent.

For the evaluation of the petroleum source-rock potential of a formation, the amount of organic matter in the rock and its thermal history are very important to consider (Clayton and Swetland, 1978). Outcrop samples provide the minimum values for organic richness measurements when unweathered subsurface samples are not available. As noted in a study of the Permian Phosphoria Formation and the Cretaceous Pierre Shale of the western United States by Clayton and Swetland (1978), the magnitude of weathering-induced changes in organic-matter composition and content is variable. There were significant weathering-induced alterations in the Phosphoria Formation samples, but not in the Pierre 
Shale samples (Clayton and Swetland, 1978). In a study of the Upper Cretaceous Mancos Shale of Utah, organic carbon content decreased up to 25 percent from unweathered subsurface samples to weathered near-surface (less than $3 \mathrm{~m}$ deep) samples (Leythaeuser, 1973). Additionally, in a study of the Lower Jurassic Posidonia Shale in northern Germany, it was determined that about 14 percent of the original organic matter was released through weathering of the outcrop samples as compared to unweathered subsurface samples (Littke and others, 1991).

The range of average reflectance $\left(\% \mathrm{R}_{0}\right)$ values in the Marcellus Shale samples from this study is consistent with the Devonian $\% \mathrm{R}_{\mathrm{o}}$ values reported by Repetski and others (2008) from drill-cuttings samples collected from locations in New York, Pennsylvania, Ohio, Maryland, Kentucky, Virginia, and West Virginia. As was previously noted (table 2; fig. 4B), most of the Marcellus Shale samples have $\% \mathrm{R}_{\mathrm{o}}$ values greater than 2 percent, which is in agreement with their location with respect to the Devonian $2.0 \% \mathrm{R}_{\mathrm{o}}$ isograd of Repetski and others (2008). The highest average reflectance value measured in the Marcellus Shale samples in this study was 3.43. Dembicki (2009) stated that vitrinite reflectance is an indicator of the cumulative time and temperature history of the sediments, but it cannot alone provide the basin history to explain the timing of generation and migration of hydrocarbons. According to Laughrey (2009) and Laughrey and others (2011), Marcellus Shale samples with average reflectance greater than $3.0 \% \mathrm{R}_{\mathrm{o}}$ were collected in gas-productive areas of Pennsylvania. According to Burruss and Laughrey (2010), natural gas samples were collected from Silurian and Ordovician reservoirs in productive fields in New York and Pennsylvania in areas of conodont CAI greater than 4 , with some samples collected from areas with CAI greater than 5 . Shales with greater than $3.0 \% \mathrm{R}_{0}$ values in the Arkoma basin of Oklahoma are gas productive (Houseknecht and Matthews, 1985; Houseknecht and others, 1992; Coleman, 2008). Several well completions in the Woodford Shale at thermal maturities greater than $3.0 \% \mathrm{R}_{\mathrm{o}}$ had initial production rates between 1 and $4 \mathrm{Mscf}$ of gas per day (Cardott, 2012).

Natural gas fields within the study area point to the preservation of gas at depth within the study area (pl. 1). The presence of gas within the Lower Devonian Oriskany Sandstone in fields within the study area suggests that there might be gas producible from one of the proposed hydrocarbon source rocks for the Oriskany Sandstone, which is the overlying Middle Devonian Marcellus Shale.

Rock-Eval analysis of the 105 Devonian samples collected and analyzed from the study area indicated that very little remaining hydrocarbon generation potential exists, since all values for S2 (convertible kerogen) are below 0.25 milligrams $(\mathrm{mg}) \mathrm{HC} / \mathrm{g}$ (hydrocarbons per gram of rock). The production index $(\mathrm{S} 1 /(\mathrm{S} 1+\mathrm{S} 2))^{1}$, a ratio of already generated hydrocarbons to potential hydrocarbons, also indicates that most of the samples represent zones that are postmature in terms of oil and gas generation (fig. 9). If these samples are representative of the Middle Devonian shales in the subsurface, then most of the potentially recoverable gas in the Marcellus Shale within the Broadtop synclinorium probably will be free gas within the fractures and enhanced pore spaces.

\footnotetext{
${ }^{1}$ For a definition of individual terms, refer to the explanation of column headings for the appendix, following the References Cited.
} 


\section{Production Index Histogram}

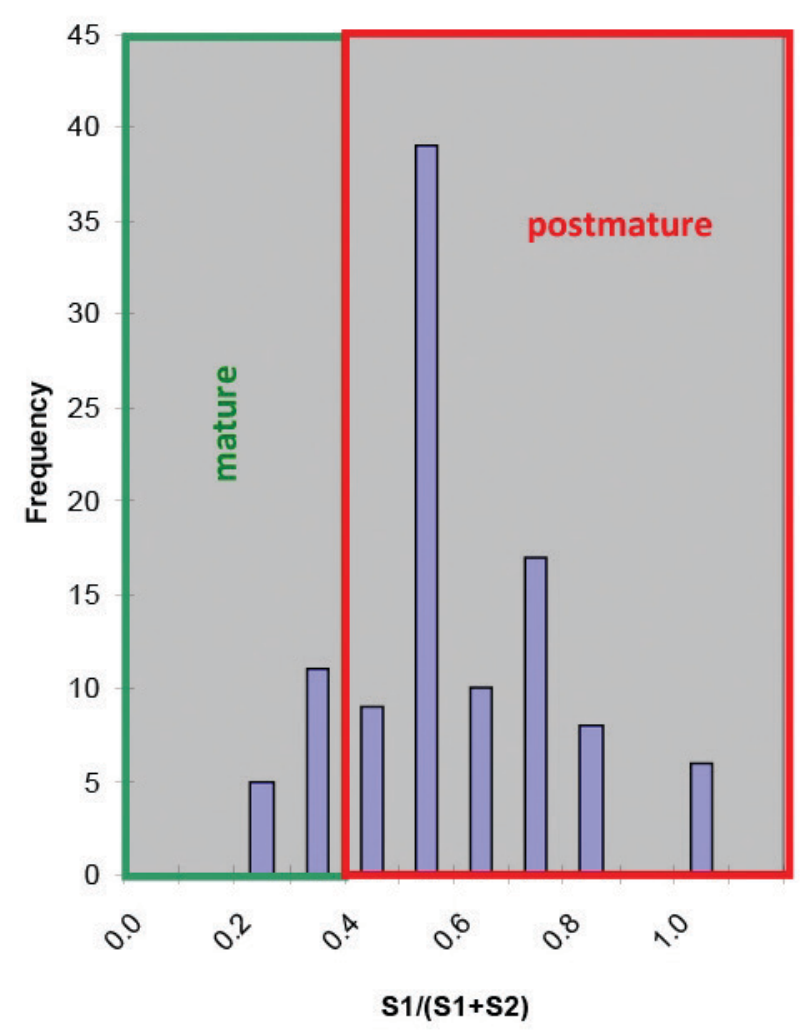

Figure 9. Histogram of production index (S1/(S1+S2)) for all 105 samples analyzed for this study.

Hosterman and Whitlow $(1981,1983)$ analyzed bulk-sample and clay-size mineralogy of 181 Marcellus Shale drill-cuttings and core samples from wells drilled in West Virginia, Virginia, Pennsylvania, Ohio, and New York. Their analysis used a different methodology for measuring bulksample mineralogy than this study, and their data were normalized to 100 percent.

The Marcellus Shale samples analyzed for this study had an average quartz content of 49 percent, which is significantly higher than the average quartz content of 20 percent reported in Hosterman and Whitlow $(1981,1983)$. Figure 10 shows the distribution of the mineral content of 87 Marcellus Shale outcrop samples analyzed in this study.

Hosterman and Whitlow $(1981,1983)$ reported average calcite content of 20 percent, while the average for this study was 5 percent. Samples in this study were collected from locations that were minimally sampled in the Hosterman and Whitlow $(1981,1983)$ study; the Broadtop synclinorium is located on the southeastern edge of the Hosterman and Whitlow $(1981,1983)$ study area, where the calcite content in the Marcellus Shale samples was lowest (fig. 15 of Hosterman and Whitlow, 1983).

Hosterman and Whitlow $(1981,1983)$ reported average clay content of 55 percent, whereas we found average clay content of 38 percent. They reported average bulk-sample chlorite content of 10 percent, average bulk-sample illite (including mixed-layer clays) content of 45 percent, and average bulk-sample kaolinite content of less than 5 percent. In contrast, we found average bulk-sample chlorite, illite (including mixed-layer clays), and kaolinite of the Marcellus Shale samples in this study to be 8 percent, 29 percent, and 1 percent, respectively. 
The average of 2 percent pyrite for the Marcellus Shale samples in this study is similar to the average of 5 percent pyrite reported by Hosterman and Whitlow $(1981,1983)$ for the 181 Marcellus Shale samples with bulk-sample and clay-size mineralogy reported.

Wang and Carr $(2012 \mathrm{a}, \mathrm{b})$ found the population distribution of quartz, clay, and carbonate mineral content from 195 core samples collected from 18 wells to be similar to that for the outcrop samples analyzed in this study. The mineral composition of Marcellus Shale core data shown in figure 5 of Wang and Carr (2012a) illustrated the dominance of quartz and clay, with a minority of samples dominated by carbonate. A similar distribution is illustrated in figure 10 of this report, showing the dominance of quartz and clay in the Marcellus Shale outcrop samples of this study.

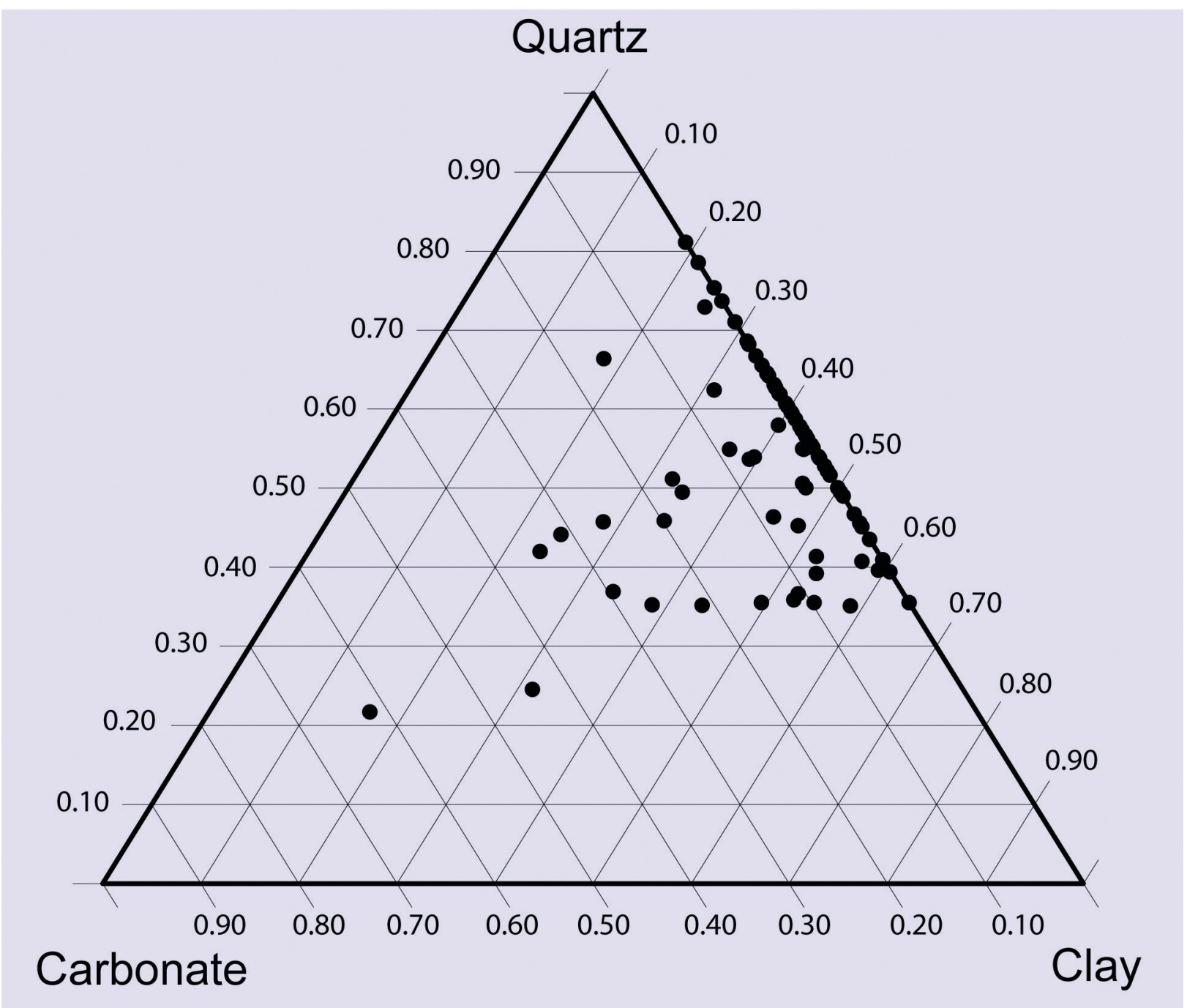

Figure 10. Ternary plot of quartz, clay, and carbonate mineral content of 87 Marcellus Shale outcrop samples analyzed in this study.

The mineralogy of the Marcellus Shale samples in this study indicates low-grade metamorphism. It is possible that smectite reacted with aluminum and potassium to produce illite, chlorite, and quartz (Hosterman and Whitlow, 1983). Hosterman and Whitlow (1983) suggested that lower calcite content may indicate a proximal relationship to a source of clastic input. The average clay content of the Marcellus Shale samples in this study is lower than the average clay content of the Marcellus Shale 
samples in the Hosterman and Whitlow (1981) study; and the illite average is 29 percent in the samples in this study versus 45 percent in the Hosterman and Whitlow (1981) study. The median illite and chlorite content of the Marcellus Shale well-core samples in Wang and Carr (2012a,b) is similar to the average illite and chlorite content in the Marcellus Shale outcrop samples in this study. The average quartz content of the samples in this study is higher than the average quartz content in the Marcellus Shale samples in the Hosterman and Whitlow (1981) study, and higher than the median quartz content of the Wang and Carr (2012a,b) Marcellus Shale samples. The high quartz content in the Marcellus Shale samples in this study may be the result of a combination of allogenic quartz (introduced at the time of deposition) and quartz derived from the conversion of smectite clay to illite clay (Hosterman and Whitlow, 1983). The mineralogy of the detrital component of this study's samples may also be influenced by the proximity of the sediment source (Dennison and others, 1996).

\section{Summary and Conclusions}

Reconnaissance field mapping and outcrop sampling for geochemical and mineralogical analyses indicate that the Middle Devonian Marcellus Shale in the Broadtop synclinorium and nearby areas from southeastern West Virginia to south-central Pennsylvania has an organic content sufficiently high and a thermal maturity sufficiently moderate to be considered for a shale gas play. The organic matter-rich Marcellus Shale is present throughout most of the study area, being absent only where it is eroded from anticlinal structures. Geochemical analyses of 128 outcrop samples and of drill-cuttings samples from four wells indicate that most if not all of the hydrocarbons have been generated and expelled from the kerogen originally in place in the mudstone. The mineralogical characteristics of the Marcellus Shale outcrop samples from the study area are slightly different from the mineralogical characteristics of Marcellus Shale samples analyzed by Hosterman and Whitlow $(1981,1983)$ and Wang and Carr (2012a,b), but that may be because the samples in this study were taken from an area of the Appalachian basin that is southeast of the areas sampled by Hosterman and Whitlow $(1981,1983)$ and Wang and Carr (2012a,b). An unknown quantity of the quartz content may be due to clay diagenesis.

The Middle Devonian shale is moderately to heavily fractured in most areas, but in some areas substantial fault shearing has removed a regular system of fractures in the Marcellus Shale.

Consequently, the ability to predict naturally preferred fracture directions as a function of rock properties and regional tectonic strain may be complicated by the shear deformation observed in the Broadtop synclinorium. Also, since the rocks are folded and faulted in the study area, the potential size of hydrocarbon drainage areas likely is smaller and less well defined than in the Allegheny Plateau, where hydrocarbon production is focused at this time.

Conventional anticlinal gas fields in the study area that are productive from the underlying Lower Devonian Oriskany Sandstone suggest that an unconventional (or continuous) shale gas system may be in place within the Marcellus Shale. Results of this study indicate that the Marcellus Shale in the Broadtop synclinorium is generally similar in organic geochemical nature throughout its extent, and there are no clearly identifiable high potential areas (or "sweet spots") in the study area based on the characteristics reported here.

\section{Acknowledgments}

Investigations which resulted in the sample collection and analyses reported herein began as an independent USGS effort to understand better the petroleum systems of the Appalachian basin and to improve our understanding of how source-rock facies form and evolve in a foreland basin. Discussion of our project led to the development of a Technical Assistance Agreement (TAA) between the USGS and 
HighMount Exploration \& Production, LLC, Houston, Tex., whereby the USGS could achieve some of its major research objectives within a few years. The authors thank Gordon Van Swearingen of HighMount Exploration \& Production, LLC, for his collaboration for the duration of the TAA. The authors also thank Gerald Wilkes (Virginia Department of Mines, Minerals, and Energy) for sharing his knowledge and unpublished field geologic quadrangle maps, and Ron McDowell (West Virginia Geological and Economic Survey) for sharing his knowledge of the geology along the Virginia-West Virginia border within the study area. We express our appreciation to Ricardo Olea (USGS) and Paul Hackley (USGS) for their reviews of this manuscript. None of this research could have been accomplished without the decades of previous work by USGS and State geological survey scientists and technicians who have sought to increase our understanding of the geology of the Devonian System shales of the Appalachian basin.

\section{References Cited}

Berryhill, H.L., Jr., Colton, G.W., de Witt, Wallace, Jr., and Johnston, J.E., 1956, Geologic map of Allegany County [Maryland]: [Baltimore, Md.,] Maryland Department of Geology, Mines and Water Resources, 1 sheet, scale 1:62,500.

Biscaye, P.E., 1964, Distinction between kaolinite and chlorite in recent sediments by X-ray diffraction: American Mineralogist, v. 49, p. 1281-1289.

Burruss, R.C., and Laughrey, C.D., 2010, Carbon and hydrogen isotopic reversals in deep basin gas; Evidence for limits to the stability of hydrocarbons: Organic Geochemistry, v. 41, no. 12, p. 12851296.

Butts, Charles, 1918, Geologic section of Blair and Huntingdon Counties, central Pennsylvania: American Journal of Science, v. 46, no. 273, p. 523-537.

Butts, Charles, 1940, Geology of the Appalachian Valley in Virginia; Part 1, geologic text and illustrations: Virginia Geological Survey Bulletin 52, 568 p.

Cardott, B.J., 2012, Thermal maturity of Woodford Shale gas and oil plays, Oklahoma, USA: International Journal of Coal Geology, v. 103, p. 109-119. [Also available at http://dx.doi.org/10.1016/j.coal.2012.06.004.]

Cardwell, D.H., 1981, Oil and gas fields of West Virginia: West Virginia Geological and Economic Survey Mineral Resources Series MRS-7A, $171 \mathrm{p}$.

Cardwell, D.H., 1982, Oriskany and Huntersville gas fields of West Virginia, with deep well and structural geologic map: West Virginia Geological and Economic Survey Mineral Resources Series MRS-5A, $180 \mathrm{p}$.

Cardwell, D.H., and Avary, K.L., 1982, Oil and gas fields of West Virginia: West Virginia Geological and Economic Survey Mineral Resources Series MRS-7B, 119 p. 
Clayton, J.L., and Swetland, P.J., 1978, Subaerial weathering of sedimentary organic matter: Geochimica et Cosmochimica Acta, v. 42, no. 3, p. 305-312. [Also available at doi:10.1016/00167037(78)90183-7.]

Coleman, J.L., Jr., 2008, Petroleum systems of the Ouachita thrust belt and foreland basins (with emphasis on the Arkoma basin), in Suneson, N.H., Cemen, Ibrahim, and Slatt, R.M., eds., Stratigraphic and structural evolution of the Ouachita Mountains and Arkoma basin, southeastern Oklahoma and west-central Arkansas; Applications to petroleum exploration; 2004 field symposium - Technical papers: Oklahoma Geological Survey Circular 112B, p. 1-15.

Cooper, G.A., 1930, Stratigraphy of the Hamilton Group of New York: American Journal of Science, v. 19, no. 110, p. 116-134.

Darton, N.H., 1896, Franklin folio, West Virginia-Virginia: U.S. Geological Survey Geologic Atlas of the United States, Folio 32, 6 p., 4 pl. [Also available at http://pubs.er.usgs.gov/publication/gf32.]

Darton, N.H., 1899, Monterey folio, Virginia-West Virginia: U.S. Geological Survey Geologic Atlas of the United States, Folio 61, 8 p., 4 pl. [Also available at http://pubs.er.usgs.gov/publication/gf61.]

de Witt, Wallace, Jr., and Colton, G.W., 1964, Bedrock geology of the Evitts Creek and Pattersons Creek quadrangles, Maryland, Pennsylvania, and West Virginia: U.S. Geological Survey Bulletin 1173, 98 p. [Also available at http://pubs.er.usgs.gov/publication/b1173.]

de Witt, Wallace, Jr., Roen, J.B., and Wallace, L.G., 1993, Stratigraphy of Devonian black shales and associated rocks in the Appalachian basin, in Roen, J.B., and Kepferle, R.C., eds., Petroleum geology of the Devonian and Mississippian black shale of eastern North America: U.S. Geological Survey Bulletin 1909, p. B1-B57. [Also available at http://pubs.er.usgs.gov/publication/b1909.]

Dembicki, Harry, Jr., 2009, Three common source rock evaluation errors made by geologists during prospect or play appraisals: American Association of Petroleum Geologists Bulletin, v. 93, no. 3, p. 341-356. [Also available at http://archives.datapages.com/data/bulletns/2009/03mar/BLTN08076/BLTN08076.htm.]

Dennison, J.M., 1970, Stratigraphic divisions of upper Devonian Greenland Gap Group (“Chemung Formation") along Allegheny Front in West Virginia, Maryland, and Highland County, Virginia: Southeastern Geology, v. 12, no. 1, p. 53-78.

Dennison, J.M., 1971, Petroleum related to Middle and Upper Devonian deltaic facies in central Appalachians: American Association of Petroleum Geologists Bulletin, v. 55, no. 8, p. 1179-1193. [Also available at http://archives.datapages.com/data/bulletns/197173/data/pg/0055/0008/1150/1179.htm.]

Dennison, J.M., 2005, Geologic field guide to Devonian stratigraphy and hydrocarbon geology near U.S. Route 250 in West Virginia and Virginia [preliminary version]: American Association of Petroleum Geologists Eastern Section meeting, September 20-22, 2005, Morgantown, W. Va., 179 p. 
Dennison, J.M., Filer, J.K., and Rossbach, T.J., 1996, Devonian strata of southeastern West Virginia and adjacent Virginia, in Geologic field guide to Devonian hydrocarbon stratigraphy of southeastern West Virginia and adjacent Virginia: Charleston, W. Va., Appalachian Geological Society Guidebook, p. 3-53. [Also available at http://archives.datapages.com/data/appalachian/Dev_Strata96/dev_strata.pdf.]

Dicken, C.L., Nicholson, S.W., Horton, J.D., Kinney, S.A., Gunther, Gregory, Foose, M.P., and Mueller, J.A.L., 2005, Preliminary integrated geologic map databases for the United States; Delaware, Maryland, New York, Pennsylvania, and Virginia: U.S. Geological Survey Open-File Report 20051325. [Also available at http://pubs.er.usgs.gov/publication/ofr20051325.]

Dow, W.G., 1977, Kerogen studies and geological interpretations: Journal of Geochemical Exploration, v. 7, no. 2, p. 79-99. [Also available at http://dx.doi.org/10.1016/0375-6742(77)90078-4.]

Dow, W.G., 1978, Petroleum source beds on continental slopes and rises: American Association of Petroleum Geologists Bulletin, v. 62, no. 9, p. 1584-1606. [Also available at http://archives.datapages.com/data/bulletns/1977-79/data/pg/0062/0009/1550/1584.htm.]

Dunne, W.M., 1996, The role of macroscale thrusts in the deformation of the Alleghanian roof sequence in the central Appalachians; A re-evaluation: American Journal of Science, v. 296, no. 5, p. 549-575. [Also available at http://dx.doi.org/10.2475/ajs.296.5.549.]

Ebright, J.R., Fettke, C.R., and Ingham, A.I., 1949, East Fork-Wharton gas field, Potter County, Pennsylvania: Pennsylvania Geological Survey, 4th Series, Bulletin M30, 43 p.

Energy Information Administration, U.S. Department of Energy, 2005, Shapefile for the Appalachian basin: Energy Information Administration Web site, accessed December 23, 2014, at http://www.eia.gov/pub/oil_gas/natural_gas/analysis_publications/maps/maps.htm\#geodata.

Enomoto, C.B., 2009, Hydrocarbon potential of the Devonian Millboro (Marcellus) Shale in the Valley and Ridge province of Virginia [abs.], in Program with abstracts, American Association of Petroleum Geologists, Eastern Section Meeting, 38th, Evansville, Ind., September 20-22, 2009: Tulsa, Okla., American Association of Petroleum Geologists, p. 36-37. [Also available at http://www.searchanddiscovery.net/abstracts/html/2009/eastern/abstracts/enomoto.htm.]

Flaherty, K.J., 1996, Play Dho; Fractured Middle Devonian Huntersville Chert and Lower Devonian Oriskany Sandstone, in Roen, J.B., and Walker, B.J., eds., 1996, The atlas of major Appalachian gas plays: West Virginia Geological and Economic Survey Publication V-25, p. 103-108.

Hackley, P.C., Ryder, R.T., Trippi, M.H., and Alimi, Hossein, 2013, Thermal maturity of northern Appalachian basin Devonian shales; Insights from sterane and terpane biomarkers: Fuel, v. 106, p. 455-462. [Also available at http://dx.doi.org/10.1016/j.fuel.2012.12.032.]

Hall, James, 1839, Third annual report of the fourth geological district of the State of New York: New York [State] Natural History Survey Geological Survey Report, v. 3, p. 287-339. 
Harper, J.A., and Patchen, D.G., 1996, Play Dos; Lower Devonian Oriskany sandstone structural play, in Roen, J.B., and Walker, B.J., eds., The atlas of major Appalachian gas plays: West Virginia Geological and Economic Survey Publication V-25, p. 109-117.

Harris, A.G., Stamm, N.R., Weary, D.J., Repetski, J.E., Stamm, R.G., and Parker, R.A., 1994, Conodont color alteration index (CAI) map and conodont-based age determinations for the Winchester $30^{\prime}$ x $60^{\prime}$ quadrangle and adjacent area, Virginia, West Virginia, and Maryland: U.S. Geological Survey Miscellaneous Field Studies Map MF-2239, scale 1:100,000. [Also available at http://pubs.er.usgs.gov/publication/mf2239.]

Hasson, K.O., and Dennison, J.M., 1988, Devonian shale lithostratigraphy, central Appalachians, U.S.A., in McMillan, N.J., Embry, A.F., and Glass, D.J., eds., Devonian of the World: Canadian Society of Petroleum Geologists Memoir 14, v. 2, p. 157-177. [Also available at http://archives.datapages.com/data/dgs/014/014002/157_cspgsp014b0157.htm.]

Hosterman, J.W., and Dulong, F.T., 1989, A computer program for semi-quantitative mineral analysis by X-ray powder diffraction, in Pevear, D.R., and Mumpton, F.A., eds., Quantitative mineral analysis of clays: CMS [Clay Minerals Society] Workshop Lectures, v. 1, p. 37-50.

Hosterman, J.W., and Whitlow, S.I., 1981, Clay mineralogy of Devonian shales in the Appalachian basin: U.S. Geological Survey Open-File Report 81-585, 198 p.

Hosterman, J.W., and Whitlow, S.I., 1983, Clay mineralogy of Devonian shales in the Appalachian basin: U.S. Geological Survey Professional Paper 1298, 31 p. [Also available at http://pubs.usgs.gov/pp/1298/report.pdf.]

Houseknecht, D.W., and Matthews, S.M., 1985, Thermal maturity of Carboniferous strata, Ouachita Mountains: American Association of Petroleum Geologists Bulletin, v. 69, no. 3, p. 335-345. [Also available at http://archives.datapages.com/data/bulletns/1984-85/data/pg/0069/0003/0300/0335.htm.]

Houseknecht, D.W., Hathon, L.A., and McGilvery, T.A., 1992, Thermal maturity of Paleozoic strata in the Arkoma basin, in Johnson, K.S., and Cardott, B.J., eds., Source rocks in the southern Midcontinent, 1990 symposium: Oklahoma Geological Survey Circular 93, p. 122-132. [Also available at http://www.ogs.ou.edu/pubsscanned/Circulars/Circular93.pdf.]

Jacobeen, Frank, Jr., and Kanes, W.H., 1974, Structure of Broadtop synclinorium and its implications for Appalachian structural style: American Association of Petroleum Geologists Bulletin, v. 58, no. 3, p. 362-375. [Also available at http://archives.datapages.com/data/bulletns/197476/data/pg/0058/0003/0350/0362.htm.]

Jacobeen, Frank, Jr., and Kanes, W.H., 1975, Structure of Broadtop synclinorium, Wills Mountain anticlinorium, and Allegheny frontal zone: American Association of Petroleum Geologists Bulletin, v. 59, no. 7, p. 1136-1150. [Also available at http://archives.datapages.com/data/bulletns/197476/data/pg/0059/0007/1100/1136.htm.] 
Jarvie, D.M., Claxton, B.L., Henk, Floyd, and Breyer, J.T., 2001, Oil and shale gas from the Barnett Shale, Fort Worth basin, Texas [abs.], in Program with abstracts, American Association of Petroleum Geologists, Annual Meeting, Denver, Colo., June 3-6, 2001: Tulsa, Okla., American Association of Petroleum Geologists, p. A100. [Also available at http://www.searchanddiscovery.com/abstracts/html/2001/annual/abstracts/0386.htm.]

Kulander, B.R., and Dean, S.L., 1986, Structure and tectonics of central and southern Appalachian Valley and Ridge and Plateau provinces, West Virginia and Virginia: American Association of Petroleum Geologists Bulletin, v. 70, no. 11, p. 1674-1684. [Also available at http://archives.datapages.com/data/bulletns/1986-87/data/pg/0070/0011/1650/1674.htm.]

Laughrey, C.D., 2009, Thermogenic gas resources in the Marcellus, Utica, and Lockatong Shales-A comparative assessment of Devonian, Ordovician, and Triassic unconventional reservoirs in Pennsylvania [abs.], in Program with abstracts, American Association of Petroleum Geologists, Eastern Section Meeting, 38th, Evansville, Ind., September 20-22, 2009: Tulsa, Okla., American Association of Petroleum Geologists, p. 43. [Also available at http://www.searchanddiscovery.com/abstracts/html/2009/eastern/abstracts/laughrey.htm.]

Laughrey, C.D., Ruble, T.E., Lemmens, Herman, Kostelnik, Jaime, Butcher, A.R., Walker, Greg, and Knowles, Wayne, 2011, Black shale diagenesis: Insights from integrated high-definition analyses of post-mature Marcellus Formation rocks, northeastern Pennsylvania: American Association of Petroleum Geologists Search and Discovery Article \#110150C2011 AAPG, 62 p. [Also available at http://www.searchanddiscovery.com/documents/2011/110150laughrey/ndx_laughrey.pdf.]

Law, C.A., 1999, Evaluating source rocks, chap. 6 of Foster, N.H., and Beaumont, E.A., eds., Exploring for oil and gas traps; Treatise of Petroleum Geology: Tulsa, Okla., American Association of Petroleum Geologists, p. 6-1 to 6-41. [Also available at http://archives.datapages.com/data/specpubs/beaumont/ch06/ch06.htm.]

Leythaeuser, Detlev, 1973, Effects of weathering on organic matter in shales: Geochimica et Cosmochimica Acta, v. 37, no. 1, p. 113-120. [Also available at doi:10.1016/0016-7037(73)90249-4.]

Littke, Ralf, Klussmann, Udo, Krooss, B.M., and Leythaeuser, Detlev, 1991, Quantification of loss of calcite, pyrite, and organic matter due to weathering of Toarcian black shales and effects of kerogen and bitumen characteristics: Geochimica et Cosmochimica Acta, v. 55, no. 11, p. 3369-3378. [Also available at doi:10.1016/0016-7037(91)90494-P.]

Milici, R.C., 1990, Oil and gas exploration and development in Virginia, 1979-1988: Virginia Minerals, v. 36, no. 1, p. 1-6. [Also available at http://www.dmme.virginia.gov/commercedocs/VAMIN_VOL36_NO01.PDF.]

Milici, R.C., and Swezey, C.S., 2006, Assessment of Appalachian basin oil and gas resources; Devonian Shale-Middle and Upper Paleozoic Total Petroleum System: U.S. Geological Survey Open-File Report 2006-1237, 70 p. [Also available at http://pubs.usgs.gov/of/2006/1237/.]

Munsell Color Company, 1954, Munsell soil color charts: Baltimore, Md., Munsell, Inc., 16 p. 
Nicholson, S.W., Dicken, C.L., Horton, J.D., Labay, K.A., Foose, M.P., and Mueller, J.A.L., 2005, Preliminary integrated geologic map databases for the United States: Kentucky, Ohio, Tennessee, and West Virginia: U.S. Geological Survey Open-File Report 2005-1324. [Also available at http://pubs.er.usgs.gov/publication/ofr20051324.]

Nickelsen, R.P., 1963, Fold patterns and continuous deformation mechanisms of the central Pennsylvania folded Appalachians, in Wagner, W.R., and Nickelsen, R.P., eds., Tectonics and Cambrian-Ordovician stratigraphy in the central Appalachians of Pennsylvania, Guidebook, Pittsburgh Geological Society and Appalachian Geological Society field trip, September 19-21, 1963: Pittsburgh, Pa., Pittsburgh Geological Society, p. 13-29. [Also available at http://archives.datapages.com/data/appalachian/tectonics_camb_ordostrat63/nickelsen.pdf.]

O’Harra, C.C., 1900, The geology of Allegany County, in Allegany County: Baltimore, Md., Maryland Geological Survey, p. 57-163.

Peters, K.E., and Moldowan, J.M., 1993, The biomarker guide; Interpreting molecular fossils in petroleum and ancient sediments: Englewood Cliffs, N.J., Prentice Hall, 363 p.

Peters, K.E., Walters, C.C., and Moldowan, J.M., 2005, The biomarker guide (2nd ed.): Cambridge, U.K., Cambridge University Press, 2 v., 1155 p.

Piotrowski, R.G., and Krajewski, S.A., 1977a, Preliminary stratigraphic cross section $\left(\mathrm{C}_{4}-\mathrm{D}_{4}\right)$ showing radioactive black shale zones and sandstones in the middle and upper Devonian, western Pennsylvania: U.S. Department of Energy Morgantown Energy Technology Center Eastern Gas Shales Project Series 5, 2 sheets.

Piotrowski, R.G., and Krajewski, S.A., $1977 b$, Preliminary stratigraphic cross section $\left(\mathrm{B}_{1}-\mathrm{B}_{4}\right)$ showing radioactive black shale zones and sandstones in the middle and upper Devonian, western Pennsylvania: U.S. Department of Energy Morgantown Energy Technology Center Eastern Gas Shales Project Series 7, 2 sheets.

Pohn, H.A., de Witt, Wallace, Jr., and Schultz, A.P., 1985, Disturbed zones, lateral ramps and their relationship to the structural framework of the central Appalachians: American Association of Petroleum Geologists, Eastern Section meeting, Williamsburg, Va., November 9-10, 1985, Guidebook, 40 p.

Pontolillo, Jim, and Stanton, R.W., 1994, Coal petrographic laboratory procedures and safety manual II: U.S. Geological Survey Open-File Report 94-631, 69 p. [Also available at http://pubs.er.usgs.gov/publication/ofr94631.]

Rader, E.K., and Biggs, T.H., 1976, Geology of the Strasburg and Toms Brook quadrangles, Virginia: Virginia Division of Mineral Resources Report of Investigations 45, 104 p., 4 pls., scale 1:24,000.

Rader, E.K., and Evans, N.H., eds., 1993, Geologic map of Virginia_Expanded explanation: Charlottesville, Va., Virginia Division of Mineral Resources, 80 p. 
Rader, E.K., and Gathright, T.M., II, comps., 2001, Geologic map of the Front Royal $30 \times 60$ minute quadrangle; Portions of Clarke, Page, Rockingham, Shenandoah, and Warren Counties, Virginia: Virginia Division of Mineral Resources Publication 162, 1 sheet, scale 1:100,000. [Also available at http://www.dmme.virginia.gov/commercedocs/PUB_162.pdf.]

Rader, E.K., McDowell, R.C., Gathright, T.M., II, and Orndorff, R.C., 2001, Geologic map of the Virginia portion of the Winchester $30 \times 60$ minute quadrangle: Virginia Division of Mineral Resources Publication 161, 1 sheet, scale 1:100,000. [Also available at http://www.dmme.virginia.gov/commercedocs/PUB_161.pdf.]

Repetski, J.E., Ryder, R.T., Weary, D.J., Harris, A.G., and Trippi, M.H., 2008, Thermal maturity patterns (CAI and $\% \mathrm{R}_{\mathrm{o}}$ ) in Upper Ordovician and Devonian rocks of the Appalachian basin; A major revision of USGS Map I-917-E using new subsurface collections: U.S. Geological Survey Scientific Investigations Map 3006, CD-format. [Also available at http://pubs.usgs.gov/sim/3006/.]

Roen, J.B., and de Witt, Wallace, Jr., 1984, Stratigraphic framework of the Devonian black shales of the Appalachian basin: U.S. Geological Survey Open-File Report 84-111, 71 p. [Also available at http://pubs.er.usgs.gov/publication/ofr84111.]

Roen, J.B., and Kepferle, R.C., eds., 1993, Petroleum geology of the Devonian and Mississippian black shale of eastern North America: U.S. Geological Survey Bulletin 1909, various chapter paginations. [Also available at http://pubs.er.usgs.gov/publication/b1909.]

Rowlands, David, and Kanes, W.H., 1972, The structural geology of a portion of the Broadtop synclinorium, Maryland and south-central Pennsylvania, in Lessing, Peter, Hayhurst, R.I., Barlow, J.A., and Woodfork, L.D., eds., Appalachian structures-Origin, evolution, and possible potential for new exploration frontiers: A Seminar: West Virginia University and West Virginia Geological and Economic Survey, p. 195-226.

Ryder, R.T., Swezey, C.S., Crangle, R.D., Jr., and Trippi, M.H., 2008, Geologic cross section $E-E^{\prime}$ through the Appalachian basin from the Findlay arch, Wood County, Ohio, to the Valley and Ridge province, Pendleton County, West Virginia: U.S. Geological Survey Scientific Investigations Map 2985, 2 sheets and 48-p. pamphlet. [Also available at http://pubs.usgs.gov/sim/2985/.]

Ryder, R.T., Crangle, R.D., Jr., Trippi, M.H., Swezey, C.S., Lentz, E.E., Rowan, E.L., and Hope, R.S., 2009, Geologic cross section $D-D^{\prime}$ through the Appalachian basin from the Findlay arch, Sandusky County, Ohio, to the Valley and Ridge province, Hardy County, West Virginia: U.S. Geological Survey Scientific Investigations Map 3067, 2 sheets and 52-p. pamphlet. [Also available at http://pubs.usgs.gov/sim/3067/.]

Schultz, A.P., 1997, Geology of the Broadtop synclinorium in the Winchester $30^{\prime} \times 60^{\prime}$ quadrangle, West Virginia: U.S. Geological Survey Open-File Report 97-143, 42 p., 1 sheet, scale 1:100,000. [Also available at http://pubs.er.usgs.gov/publication/ofr97143.] 
Stose, G.W., and Swartz, C.K., 1912, Pawpaw-Hancock folio, Maryland-West Virginia-Pennsylvania: U.S. Geological Survey Geologic Atlas of the United States, Folio 179, 37 p. [Also available at http://pubs.er.usgs.gov/publication/gf179.]

Swartz, F.M., 1939, Keyser Limestone and Helderberg Group, in The Devonian of Pennsylvania: Pennsylvania Geological Survey Bulletin G19, 4th Series, p. 29-91.

Tilton, J.L., Prouty, W.F., Tucker, R.C., and Price, P.H., 1927, Hampshire and Hardy Counties: West Virginia Geological Survey County Report CGR-8, 624 p.

Tissot, B.P., and Welte, D.H., 1984, Petroleum formation and occurrence (2d ed.): Berlin, Germany, Springer-Verlag, $699 \mathrm{p}$.

Vanuxem, Lardner, 1839, Third annual report of the geological survey of the third district: New York Geological Survey Annual Report, no. 3, p. 241-285.

Wang, Guochang, and Carr, T.R., 2012a, Methodology of organic-rich shale lithofacies identification and prediction; A case study from Marcellus Shale in the Appalachian basin: Computers \& Geosciences, v. 49, p. 151-163. [Also available at http://dx.doi.org/10.1016/j.cageo.2012.07.011.]

Wang, Guochang, and Carr, T.R., 2012b, Marcellus Shale lithofacies prediction by multiclass neural network classification in the Appalachian basin: Mathematical Geosciences, v. 44, no. 8, p. 975-1004. [Also available at http://dx.doi.org/10.1007/s11004-012-9421-6.]

Willard, Bradford, 1935, Hamilton Group of central Pennsylvania: Geological Society of America Bulletin, v. 46, no. 2, p. 195-224. [Also available at http://dx.doi.org/10.1130/GSAB-46-195.]

Willard, Bradford, 1939, Middle Devonian, Stroudsburgian Stage, chap. 4 of Middle and Upper Devonian, in The Devonian of Pennsylvania: Pennsylvania Geological Survey Bulletin G19, 4th Series, p. 131-160.

Woodrow, D.L., Dennison, J.M., Ettensohn, F.R., Sevon, W.T., and Kirchgasser, W.T., 1988, Middle and Upper Devonian stratigraphy and paleogeography of the central and southern Appalachians and eastern Midcontinent, U.S.A., in McMillan, N.J., Embry, A.F., and Glass, D.J., eds., Devonian of the World: Canadian Society of Petroleum Geologists Memoir 14, v. 1, p. 277-301. [Also available at http://archives.datapages.com/data/cspg_sp/data/014/014001/277_cspgsp014a0277.htm.]

Woodward, H.P., 1943, Devonian System of West Virginia: Morgantown, W. Va., West Virginia Geological Survey [Report], v. 15, 655 p. 


\section{Explanation of Column Headings for Appendix}

[Units of measurement used: mi, mile; mg, milligram; g, gram; ${ }^{\circ} \mathrm{C}$, degrees Celsius]

GPS Waypoint: Sequentially recorded location of collected samples and field measurements.

Date: Date sample or measurement was collected.

USGS Number: Sequential number assigned to samples by order of collection with an alphabetic prefix indicative of the topographic quadrangle name. Quadrangle name shown in Column O.

Secondary Identifier: May be a split of original sample, unique well identifier, and so forth.

Locality: Geographic location of collected sample, such as name of town.

General Location: Description of specific location from which sample was collected. Abbreviations used: US, U.S. Route; SR, State Route; CR, County Route.

Formation Sampled: As determined by USGS researchers in the field.

Latitude: Recorded by GPS instrument, in decimal degrees.

Longitude: Recorded by GPS instrument, in decimal degrees.

Strike: Bearing, in degrees, of line formed by intersection of the rock bedding surface with a horizontal plane.

Dip: Acute angle, in degrees, between the rock bedding surface and a horizontal plane; measured perpendicular to strike.

Outcrop Formation: As shown on published maps. This may differ from "formation sampled" above.

System: Geologic system or period, as determined from published maps.

Lithology: As determined by USGS researchers in the field.

Quadrangle Name: Based on geographic location of collected sample.

County: Based on geographic location of collected sample.

State: Based on geographic location of collected sample.

Leco TOC: Total organic carbon, in weight percent, measured on Leco instrument and provided on report archived at USGS.

S1: Volatile hydrocarbon $(\mathrm{HC})$ content, in $\mathrm{mg} \mathrm{HC} / \mathrm{g}$ rock; represents amount of free hydrocarbons in sample. 
S2: Remaining $\mathrm{HC}$ generative potential, in $\mathrm{mg} \mathrm{HC/g}$ rock; represents amount of hydrocarbons generated through thermal cracking of nonvolatile organic matter.

S3: Carbon dioxide content, in $\mathrm{mg} \mathrm{CO}_{2} / \mathrm{g}$ rock; represents amount of $\mathrm{CO}_{2}$ produced during pyrolysis of kerogen.

$\mathbf{T}_{\max }$ DegC: Temperature in ${ }^{\circ} \mathrm{C}$ at which S2 reaches its maximum; indication of stage of maturation of organic matter.

Calculated $\% \mathbf{R}_{\mathbf{0}}$ : Average reflectance $\left(\% \mathrm{R}_{\mathrm{o}}\right)$ estimated from $\mathrm{T}_{\max }$ using the following formula: $(0.018$ $\left.\mathrm{x} \mathrm{T}_{\max }\right)-7.16=1.01 \% \mathrm{VR}_{\mathrm{o}}$, where $\mathrm{VR}_{\mathrm{o}}$ represents $\% \mathrm{R}_{\mathrm{o}}$ (Jarvie and others, 2001).

Measured $\% \mathbf{R}_{\mathbf{0}}$ : Measured average reflectance by measuring reflectivity of individual grains of organic matter in rock sample under a microscope.

HI: Hydrogen index, represented by (S2 x 100) / TOC, in mg HC/g TOC.

OI: Oxygen index, represented by (S3 x 100) / TOC, in $\mathrm{mg} \mathrm{CO}_{2} / \mathrm{g}$ TOC.

S2/S3: Amount of hydrocarbons which can be generated relative to the amount of organic $\mathrm{CO}_{2}$ released during pyrolysis up to $390{ }^{\circ} \mathrm{C}$.

S1/TOC: S1/TOC x 100 (Volatile hydrocarbon content divided by total organic carbon content times 100) gives a "normalized oil content" value.

PI: Production index, represented by S1 / $(\mathrm{S} 1+\mathrm{S} 2)$; used to characterize the evolution level of organic matter.

$\mathbf{\%} \mathbf{R}_{\mathbf{0}}$ : Average reflectance, compiled for all samples, regardless of source. Report might not be archived at USGS.

TOC: Total organic carbon, in weight percent, compiled for all samples, regardless of source. Report might not be archived at USGS.

Sheared: Indicates whether the sample collected was from a zone containing shear features by having " 1 " for an affirmative observation and " 0 " for a negative observation.

Quartz\%: Estimated weight percent of quartz; values were not normalized to 100 percent.

Feldspar\%: Estimated weight percent of potassium feldspar and plagioclase; values were not normalized to 100 percent.

Carbonate\%: Estimated weight percent of calcite, siderite, dolomite, and ankerite; values were not normalized to 100 percent.

Illite\%: Estimated weight percent of illite and illite-smectite mixed clays; values were not normalized to 100 percent.

Kaolinite\%: Estimated weight percent of kaolinite; values were not normalized to 100 percent. 
Chlorite\%: Estimated weight percent of chlorite; values were not normalized to 100 percent.

Pyrite\%: Estimated weight percent of pyrite, marcasite, and sphalerite; values were not normalized to 100 percent.

Other\%: Estimated weight percent of other constituents not listed above; values were not normalized to 100 percent.

Summed Clay\%: Sum of the estimated weight percent of illite, illite-smectite mixed clays, kaolinite, and chlorite.

Mineralogy Summed\%: Sum of the estimated weight percent of quartz, feldspar, carbonate, illite, illite-smectite mixed clays, kaolinite, chlorite, pyrite, and other minerals for each sample. 
ISSN 2331-1258 (online)

http://dx.doi.org/10.3133/ofr20151061 